\title{
DESCRIPTION OF A NEW SPECIES OF EPICAUTA DEJEAN, 1834 FROM MEXICO WITH A REVIEW OF THE EPICAUTA CUPRAEOLA SPECIES GROUP (COLEOPTERA, MELOIDAE)
}

\author{
M. García-París ${ }^{1 *} \&$ J. L. Ruiz ${ }^{2}$
}

\begin{abstract}
M. García-París \& J. L. Ruiz. 2013. Description of a new species of Epicauta Dejean, 1834 from Mexico with a review of the Epicauta cupraeola species group (Coleoptera, Meloidae). Grael/sia, 69(1): 57-77.

We describe a morphologically remarkable new species of the Epicauta cupraeola species group from the highlands of the State of Nayarit, Mexico. The external appearance of Epicauta cora sp. nov., is similar to that of Epicauta rufipennis and Epicauta diana, but it is distinct from both species based on male antennae structure, shape and pilosity of the head and pronotum, color of pronotal pilosity, and male fore-tarsal structure. The nine species integrating now the E. cupraeola species group have been revised. This study of 323 specimens, including diverse type material, confirms the synonymy of Cantharis rufescens with Epicauta basimacula first proposed by Pinto (1991), and reports new geographic records for Mexican taxa. The species of the E. cupraeola group are included in a key and illustrated photographically, including type specimens of five taxa. A phylogenetic re-analysis of the $E$. cupraeola species group results in the placement of the new species as sister to E. rufipennis, which together form a sister clade to the remaining species of the E. cupraeola group.
\end{abstract}

Key words: Coleoptera; Meloidae; Epicauta cora new species; Epicauta cupraeola species group; Taxonomy; Biodiversity; America; Mexico; Nayarit.

\section{RESUMEN}

M. García-París \& J. L. Ruiz. 2013. Descripción de una especie nueva del género Epicauta Dejean, 1834 de México y revisión del grupo de especies de Epicauta cupraeola (Coleoptera, Meloidae). Graellsia, 69(1): 57-77.

Se describe una especie nueva, morfológicamente singular, del grupo de especies de Epicauta cupraeola de las zonas altas del Estado de Nayarit, México. La apariencia externa de Epicauta cora sp. nov., es similar a la de Epicauta rufipennis y Epicauta diana, pero difiere de ambas en la estructura de las antenas del macho, forma y pilosidad de la cabeza y pronoto, y estructura de las tibias anteriores del macho. Se revisan las nueve especies incluidas ahora en el grupo de especies de E. cupraeola. Este estudio que incluye 323 especímenes, entre ellos material tipo diverso, confirma la sinonimia de Cantharis rufescens con Epicauta basimacula propuesta por Pinto (1991), y aporta nuevos registros geográficos para las especies de México. Se presenta una clave para las especies del grupo de E. cupraeola y se ilustran foto-

Museo Nacional de Ciencias Naturales, MNCN-CSIC. José Gutiérrez Abascal, 2. 28006 Madrid, Spain.

2 Instituto de Estudios Ceutíes. Paseo del Revellín, 30, Apartado 593. 51080 Ceuta, Spain.

* Author for correspondence: mparis@mncn.csic.es 
gráficamente, incluyendo ejemplares tipo de cinco taxones. Un nuevo análisis filogenético del grupo de $E$. cupraeola indica que la especie nueva se sitúa como grupo hermano de $E$. rufipennis, de forma que juntas constituyen el clado hermano de las demás especies del grupo.

Palabras clave: Coleoptera; Meloidae; Epicauta cora nueva especie; grupo de especies de Epicauta cupraeola; Taxonomía; Biodiversidad; América; México; Nayarit.

\section{Introduction}

Epicauta Dejean, 1834, is one of the most diversified genera within the family Meloidae. With more than 360 species distributed between two subgenera, Epicauta is also one of the genera with the widest geographic range: its species are distributed over most of the world's continental areas, excluding Australia (Pinto \& Bologna, 1999; Bologna \& Pinto, 2002). The genus is particularly diversified in America, where approximately $75 \%$ of the known species are found. The North American fauna, comprising 173 species, arranged into 32 species groups, has been the subject of a thorough review by Pinto (1991).

Pinto (1991), using morphological and behavioral traits, arranged the 101 North American species of the subgenus Epicauta into 18 species groups; some of these groups were previously proposed by Werner $(1945,1954)$ and Adams \& Selander (1979). Although generally straightforward, some species group definitions are based on few characters, which may be poorly developed in certain species. While the remarkable morphological diversity within some of the species groups suggests little internal cohesion and the possible lack of monophyly, the usefulness of groupings is evident in such a speciose genus. In the absence of an exhaustive phylogenetic analysis, these groups represent a valid taxonomic framework for the study and discussion of characters and the facilitation of species diagnosis.

Although proposed on the basis of few constant characters, one of the apparently cohesive species groups is the Epicauta cupraeola group. This species group was proposed by Pinto (1991) for eight species: E. basimacula (Haag-Rutenberg, 1880), E. crassitarsis Maydell, 1935, E. cupraeola (Dugès, 1869), E. diana Pinto, 1991, E. leucocoma Champion, 1892, E. pedalis LeConte, 1866, E. rufipennis (Chevrolat, 1834), and E. tenebrosa Werner, 1949. The definition of the E. cupraeola group is based primarily on the antennal modifications of males, which are poorly expressed in some species (Pinto, 1991). These antennal modifications consist of a slight anteroapical curvature of segment I, which protrudes over segment II as an apical lip, and of a subtle bow of segment III with the posterior surface concave and the anterior surface convex, resulting in a somewhat sinuate appearance dorsally. Although males in all of these species have a single (posterior) fore tibial spur, this character is also shared with the males of the E. nigritarsis and E. maculata species groups. Most species of the E. cupraeola group, particularly the species with dark elytra, have light-colored legs or show marked color contrast between the yelloworange elytra and the dark prothorax and head. The combination of these characters provides consistent group identifications.

All species of the E. cupraeola group inhabit Mexico. Three species penetrate southwards: one as far as Costa Rica (E. cupraeola) and the other two into Guatemala (E. basimacula and E. rufipennis). Three other species extend northwards into the USA (E. tenebrosa, E. crassitarsis, and E. cupraeola) (Pinto, 1991; García-París et al., 2007). The phylogenetic relationships between species have been inferred using morphological characters (Pinto, 1991). The resulting eight equally parsimonious trees had poor support, as is generally the case when the number of characters is limited by adult morphological data. Pinto (1991) proposed the use of the tree most consistent with overall si-milarity as the most likely phylogenetic hypothesis. This proposal placed E. rufipennis, the only species of the group known at that time with black legs, as sister to all of the other taxa. This tree also showed a sister relationship between E. basimacula and E. diana, which partly share antennal modifications, and which in turn, are sister to the remaining species.

Following the examination of the Mexican Epicauta specimens held at the Colección Nacional de Insectos (CNIN) of the Instituto de Biología (IB) of the Universidad Nacional Autónoma de México (UNAM), we found a single male specimen of an undescribed species of the E. cupraeola species group, phenetically similar to E. rufipennis and $E$. 
diana by its coloration pattern, pilosity, and general proportions, but with extreme antennal modifications consisting of a unique broadly inflated segment I (the remaining antennal segments were similar to those of E. cupraeola). The peculiar morphological characteristics of this undescribed species prompted us to phylogenetically re-analyze the morphological data presented by Pinto (1991) with the addition of this new taxon.

The objectives of this work are (1) to describe the new Mexican species, (2) to propose a phylogenetic hypothesis for the E. cupraeola species group, including the new species, (3) to discuss certain nomenclatural and geographical issues, and (4) to provide photographic illustrations of all taxa and a key to facilitate the identification of the species of the E. cupraeola group.

\section{Materials and methods}

The basis for this study were 323 specimens of the E. cupraeola species group examined in the following collections: the Colección Nacional de Insectos of the Instituto de Biología of the Universidad Nacional Autónoma de México (CNIN-IBUNAM), the Natural History Museum of Los Angeles County, California (NHMLA), the M. A. Bologna collection at Roma Tre University, Roma (MAB), the Museo del Instituto de Zoología Agrícola of the Universidad Central de Venezuela, Maracay (MIZA), the Hungarian Natural History Museum (Magyar Természettudományi Múzeum) of Budapest (HNHM), and the Natural History Museum of London (BMNH) (Appendix I). Among the materials studied, including types from various taxa (see Appendix I), we found a single male from the Mexican State of Nayarit, representing an unknown species described herein. The CNINIBUNAM collection is the depository for materials used by Eugenio Dugès for the revision of the Mexican Meloidae, published from 1869 to 1889 (see Zaragoza-Caballero, 1999, and García-París et al., 2007, for a bibliographical listing of E. Dugès works on Meloidae). Although E. Dugès described many species, including E. cupraeola, only a few type specimens remain available (Vázquez \& Zaragoza, 1979). Additional type specimens of the E. cupraeola group were studied at the BMNH (London) and MIZA (Maracay) (see species accounts). Type and representative specimens were photographed to illustrate general habitus. Morphological characters of dry mounted specimens were studied under the stereomicroscope; genitalia were extracted and mounted on cards. The species description follows the structure of those of Pinto (1991).

Phylogenetic analyses were performed using the characters proposed by Pinto (1991), with some modifications based on additional information provided by the specimens studied (Appendix II). Outgroup choice of E. nigritarsis, proposed to be the sister taxon of the E. cupraeola species group, was based on the phylogenetic analysis presented by Pinto (1991); consequently character states shared with E. nigritarsis were coded as 0 . A distant outgroup (E. vittata or E. maculata species groups) was selected when character states shown by the $E$. cupraeola species group were not present in $E$. nigritarsis. The final matrix included 13 characters (Appendix II), two of which were not phylogenetically informative. Analyses were run using unweighted Maximum Parsimony (MP) with the exhaustive search algorithm, using the computer program PAUP*4.0b10 (Swofford, 2002). We used nonparametric bootstrapping (1000 pseudoreplicates) to assess the stability of internal branches in the resulting topologies, using a maximum parsimony branch and bound approach (Parra-Olea et al., 2004).

\section{Results}

Epicauta (Epicauta) cora García-París et Ruiz sp. nov.

Holotypus: México. Nayarit. Río Huaynamota, Los Sabinos. 8/11-VI-1991. R. Barba, E. Barrera [white label, printed] // Holotypus Epicauta (Epicauta) cora García-París et Ruiz des. 2013 [red label, printed]. CNIN-IBUNAM.

DESCRIPTION OF HOLOTYPE (male) (Figs. 1a-d, and Figs. 2a-c): Moderately slender, elongated, length $12.2 \mathrm{~mm}$; maximum width (fourth elytral fifth) 3.6 $\mathrm{mm}$. Head, thorax, scutellum and venter with black cuticle, with shiny luster, mostly covered by dense silvery-white vestiture. Legs and antennae dark brown to black. Elytra orange brown with short dense golden-yellow vestiture (Fig. 1a, b).

Head (form clypeus-front suture to vertex: 1.7 $\mathrm{mm}$; maximum width at temples, just above eyes: $1.95 \mathrm{~mm}$ ) suborbicular, shiny black with a small red-orange poorly marked frontal spot, with subparallel non-prominent temples, with a complete 

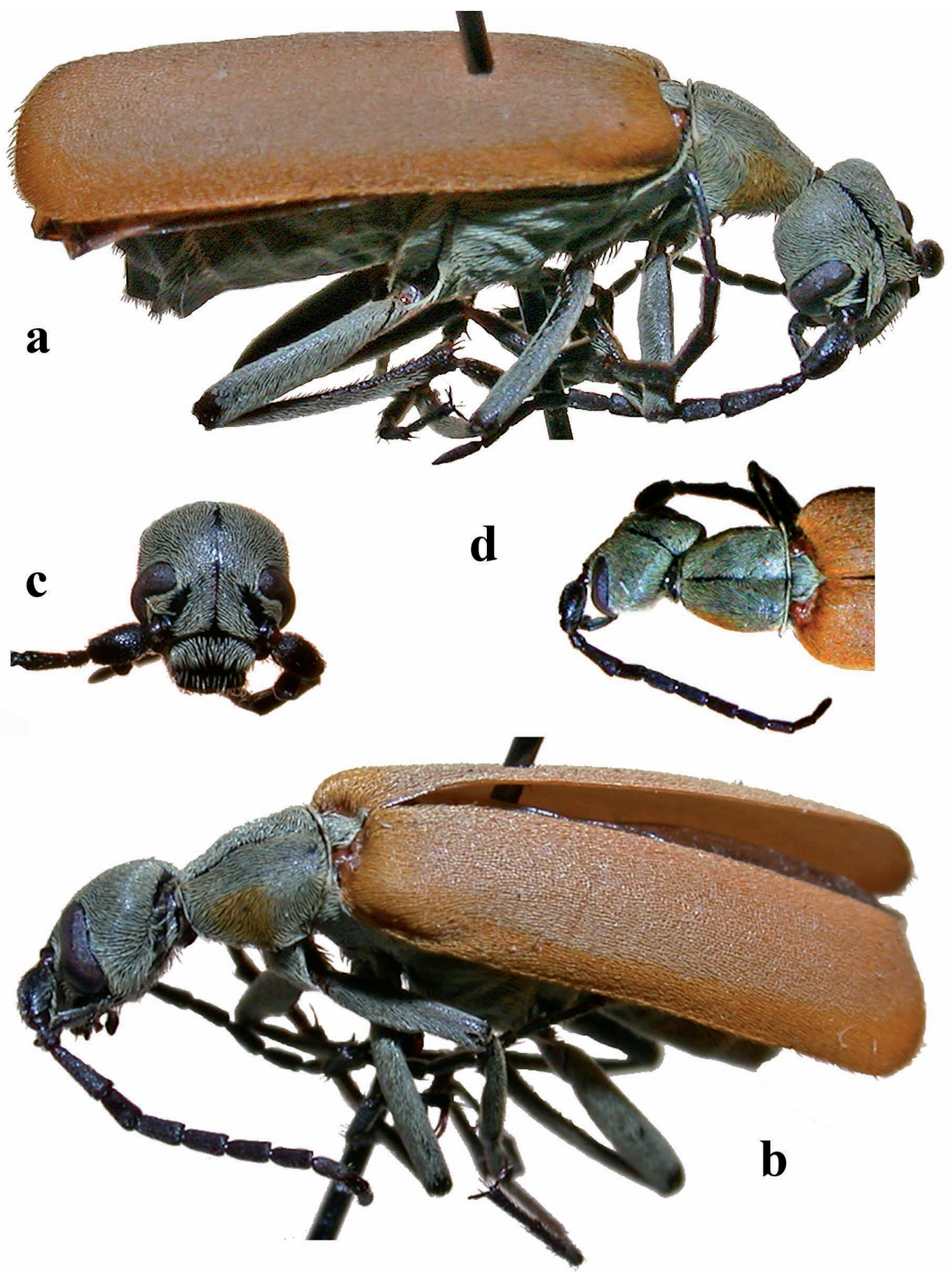

Fig. 1.- Habitus of the holotype of Epicauta cora: a) dorsal view; b) lateral view; c) head; d) dorsal view of pronotum. Fig. 1.- Habitus del holotipo de Epicauta cora: a) vista dorsal; b) vista lateral; c) cabeza; d) vista dorsal del pronoto. 
nitid longitudinal median groove from the frontoclypeal suture to the end of the vertex; two markedly elevated convergent denuded smooth areas (calluses), that are placed in parallel to the internal edge of the eye, above antennal insertions, ending just before the frons central region; antennal insertions raised above head level; large, moderately bulged eyes with the interior margin strongly emarginated, dividing the eye into two lobes, the inferior larger. Eyes entirely bordered with a thin denudated low rim. Head surface covered with fine dense punctures uniformly distributed, except along the midline, the two raised juxtaocular areas and the clypeo-frontal suture which are smooth; integument among punctures micro-reticulate. Frontoclypeal suture arcuate. Clypeus sub-rectangular, transverse ( $1.15 \mathrm{~mm}$ wide by $0.5 \mathrm{~mm}$ long), with parallel sides, with the distal third membranous and denuded. Clypeal punctures larger and less dense than those of head surface; micro-reticulate integument. Labrum subtrapezoidal, transverse $(0.95 \mathrm{~mm}$ wide by $0.35 \mathrm{~mm}$ long). Mandibles short, widely curved on the external side, mostly covered by clypeus and labrum while resting. Labral punctures as on clypeus but shallower and less dense. Vestiture of head surface, dense, each seta corresponding to a puncture, and formed by straight short, silvery-white setae, applied against tegument, directed forward in the posterior half, and towards the sides in the anterior half, except vestiture bordering the internal margin of the eye, which is directed towards the calluses (Fig. 1c). Clypeal pilosity as that on head but longer and partly erect, directed forward. Labral pilosity formed by sparse setae, thinner than those of clypeus and head capsule; five isolated setae, curved at the distal end where they turn to red-brown, placed at the middle of the anterior margin of labrum. Maxillary palpi with wide segments, subtrapezoidal, strongly asymmetrical, dorsoventrally flattened, with the distal segment widest; distal segment with a narrow dorsal excavation, shallow but well marked, placed at the external side near the anterior margin (Fig. 1). Labial palpi with segments I subcylindrical, II troncoconical but narrow, and III subellipsoidal. Pilosity of maxillary palpi short and erect, sparse and uniformly distributed except on the apical third of the last segment, subglabrous.

Antennae slightly surpassing the humeral region of elytra. Antennal segments I to VIII black, IX to XI turning dark brown, and XI lighter. Segment I conspicuously inflated, widest at the middle, narrowing towards the base, 1.9 times longer than wide, 3.5 times longer than segment II, and 1.2 times longer than segment III, with a slight anteroapical curvature, which protudes over segment II forming an apical lip (Fig. 1a, b, d). Segment II short and troncoconical, 1.3 times longer than wide. Segment III subcylindrical, long, widest at the apex, slightly concave posteriorly (difficult to see), 2.6 times longer than wide, 2.5 times longer than segment II, 1.32 times longer than IV. Segments IV to XI slightly flattened laterally (compressed). Segment IV, 2 times longer than wide, with subparallel sides, slightly broader towards the apex, 0.75 times shorter than III. Segments V to IX subequal, with subparallel sides broadening towards the apex, approximately 1.8 times longer than wide, slightly shorter than IV. Segment X slightly narrower than segments V to IX, with almost parallel sides, 2 times longer than wide. Segment XI slightly narrower than $\mathrm{X}, 1.3$ times longer than $\mathrm{X}$, with apex rounded, blunt. Segment I with short sub-appressed, brown-reddish sparse pilosity on the anterior part and a few silvery-white setae on the posterior half. Segment II with reddish-brown sparse pilosity. Segment III with dense, very short reddishbrown pilosity. Segments IV to XI with very short reddish, sub-appressed pilosity; inferior part of the anterior surface of segments IV to VII with a few long, thin, curved grayish translucent setae; inferior part of the anterior surface of VIII to X with a few sparse grayish translucent erect setae half the length of the long setae of segments IV to VII. Inferior part of the anterior surface of segment XI with sparse dispersed erect grayish translucent short setae.

Pronotum, elongate, with a general subcampanulate shape (1.95 mm long; $1.07 \mathrm{~mm}$ wide; maximum width at the middle) (Fig. 1d), black with a shiny luster; lateral sides subparallel in the posterior half, and slightly convergent towards the anterior margin in the anterior half; anterior half surface in slight declivity towards the anterior margin; a shallow, but well marked median longitudinal groove, smooth and denudated at the anterior half, and with scarce pilosity along the posterior half (Fig. 1d); anterior and posterior pronotal margins finely but distinctly bordered by a thin rim; dorsal punctures fine and dense, slightly larger than in the head, slightly raised giving a grainy appearance; micro- 
reticulate tegument; pilosity applied against tegument, silvery-white except in the anterior half of the sides, which turns to ochreous-yellow (Fig. 1a, b); pilosity of the anterior half, including late-ral sides directed towards the posterior part of the body; the pilosity of the discal portion of the posterior half directed more or less laterally; the pilosity placed near the posterior rim directed forward diverging towards the sides; setae of the anterior and posterior margins of the pronotum, erected divergently directed towards the sides. Propleural pilosity directed dorsally. Visible portion of the mesonotum (when thorax depressed) 1.5 times wider than long, subtriangular, black with a shiny luster, punctures and pilosity as in pronotum without marked median line; scutellum narrow, raised over the elytra. Elytra uniformly ochreous-yellow, elongate, with subparallel sides (3.8 $\mathrm{mm}$ long, $1.5 \mathrm{~mm}$ maximum width) broadly rounded at the apex; humeri slightly prominent, rounded; finely and densely punctured all over; pilosity golden-yellow, short, applied against the tegument, directed backwards, dense; apex with a few longer setae that surpass the elytral margin. Prosternum, mesosternum, and coxae covered by a dense silvery-white recumbent pilosity consisting of setae thicker and longer than those of pronotum.

Legs relatively long; femora and tibiae covered by dense pilosity fine and short, whitish-yellow at the femora turning progressively to golden-yellow at the distal portion of tibiae. Ventral side of fore femora and tibiae with an impressed depression covered with golden-yellow pilosity. Fore tibiae with a single straight distal spur, uniformly narrow, straight. Median tibiae with two equal, straight apical spurs. Hind tibiae with two apical spurs, onethird shorter than those of the median tibiae, thicker and dissimilar, pallid at apical third; inner spur slightly longer, stick-like, narrower; outer spur narrowly, obliquely truncate at apex. Tarsi long and slender, with tarsal segments subcylindrical, segment I of fore leg symmetrical, narrow, a little wider at the apex than at the base, less than onethird as wide as long in dorsal view (length/width ratio $=3.57$ ). Meso- and metarsal ventral pads consisting of a dense tuft of short dense golden-yellow setae, except along a denuded median line. Tarsal claws narrow, curved and with the inferior lobe as long as the superior, with a rounded ventral denticle at the basal portion of the inferior lobe.

Abdominal sterna covered by dense, silverywhite pilosity, applied against the surface, almost concealing the black shiny tegument. Last visible abdominal sternum slightly emarginate at the apex; surface of the anterior half with silvery-white short setae and of the posterior half with reddish-brown setae, progressively increasing in length towards the apex. Pygidium and propygidium with dense pilosity, but shorter, thinner and less dense than that of sterna.

Male genitalia (Fig. 2) typical of the E. cupraeola species group, including gonoforceps with basal segment wide and short, about one half the length of the gonostyli; gonostyli distally curved in lateral view (Fig. 2a), deeply but narrowly cleaved in dorsal view (Fig. 2b), with some whitish thin setae on the latero-distal portion of the ventral side. Aedeagus widest at the middle on lateral view (Fig. $2 \mathrm{c})$, with the apical hook weakly curved, including an inferior side almost straight; dorsal hook strongly curved.

DiAgNOSIS AND COMPARISONS. Epicauta cora is characterized as follows: elytra entirely pale, head, pronotum, venter, and legs dark brown to black; antennae of male not distinctly ensiform, all segments elongate, segment I in male markedly inflated; fore-tibial spur in male straight; fore tarsal segment I in male elongate, narrow, less than onethird wide as long.

The external appearance of this species is, at first glance, similar to that of E. rufipennis and $E$. diana (Figs. 1, 3). It is distinguishable from $E$. diana (Fig. 3b, c) by the following characters: (1) male antennae in $E$. diana are almost one-third shorter; segment I subconical but not inflated; segments V to XI transverse; inferior part of the anterior surface of segments IV to VII without the characteristic long, thin, curved grayish-clear setae of E. cora; (2) pronotum in E. diana is more transverse, almost as long as wide, while in E. cora, it is longer than wide; longitudinal denuded midline almost three times broader than in $E$. cora; in $E$. diana, color of pronotal pilosity silvery-cinereous, without lateral orange patches; (3) male fore tarsal structure: fore tarsi less elongate, with tarsomeres broader than in E. cora; male tarsal segment I in $E$. diana in dorsal view evidently shorter and broader (length/width: $5 / 2.1=2.4$ ) than in E. cora; (4) leg coloration dark orange in E. diana, black in E. cora. Additionally, the pilosity on the head is often reddish-orange and denser in E. diana, although there is some variability in these characters across the specimens studied. 

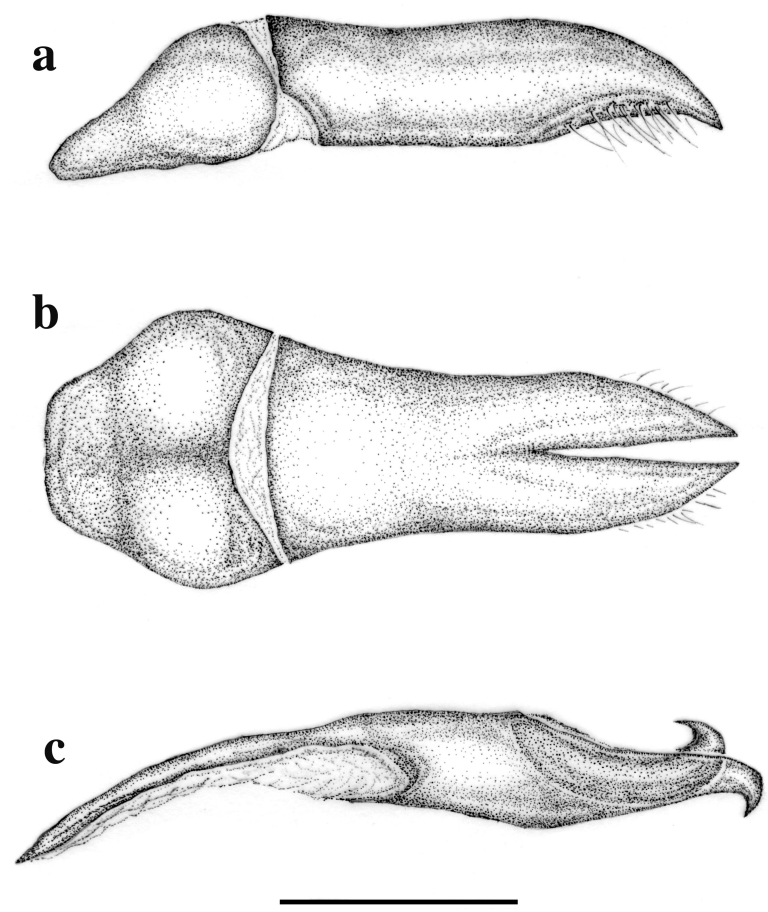

Fig. 2.- Male genitalia of Epicauta cora (holotype): a) gonoforceps, lateral view; b) gonoforceps, dorsal view; c) aedeagus, lateral view (scale bar $=0.5 \mathrm{~mm}$ ).

Fig. 2.- Genitalia masculina del holotipo de Epicauta cora: a) vista lateral y b) dorsal del tegmen; c) vista lateral del edeago. Escala: 0,5 mm.

Epicauta cora is distinguishable from E. rufipennis (Fig. 3a) as follows: (1) male antenna approximately one-fourth longer in E. rufipennis; segment I subconical, not inflated in E. rufipennis; antennomeres IV to VI of E. rufipennis without the characteristic long, woolly setae along the anterior side of $E$. cora antennae; (2) head with the longitudinal denuded, smooth midline, four times broader than in E. cora; head pilosity generally orange in E. rufipennis with semi-erect rather than decumbent setae; (3) pronotum in E. rufipennis is more transverse, almost as long as wide, whereas it is longer than wide in $E$. cora; less dense pilosity and shallower pronotal punctures in E. rufipennis; longitudinal denuded midline almost four times broader than in E. cora; pronotal pubescence semi-erect in E. rufipennis, not decumbent; in E. rufipennis, color of pronotal pilosity silvery-cinereous without lateral orange patches.

Epicauta cora can be distinguished at first glance from all other North American species of
Epicauta by the characters indicated in the key (see below).

GEOGRAPHIC Distribution. Only known from the type locality, near Los Sabinos along the Huaynamota River in the Municipio El Nayar (State of Nayarit, Mexico). The area where the species was found is located in the interior mountain region of the State of Nayarit, along the Sierra Madre Occidental. The main climate in this region is hot and subhumid with rainfall in the summer; the rainiest months are from June to September. The average annual rainfall is $754 \mathrm{~mm}$. The average annual temperature is $25{ }^{\circ} \mathrm{C}$ (Barrón Mayorquín, 2005). Ecological conditions similar to those of the type locality can be found along a wide area of the Sierra del Nayar, a rugged country, difficult to access and, entomologically, little explored.

ETYMOLOGY. The epithet "cora" (a noun in apposition) refers to the Cora, an ethnic group, who together with the Huichol are the brave native people of the Municipio El Nayar, where the type locality (Los Sabinos) of this species is integrated. The name El Nayar was given to the Municipio in honor of the Cora chief Nayar or Nayarit.

The color yellow, which is prominent on the township shield of El Nayar, is a symbol of prosperity (Barrón Mayorquín, 2005), and because of its resemblance with the yellow-orange color of the elytra of E. cora, we hope this species will be also a symbol of prosperity and environmental health for the people of the Sierra de Nayarit.

\section{Identification key to males of the Epicauta cupraeola group}

Because the female of E. cora is still unknown, the following key is based exclusively on male characters. The key distinguishes males of all the species of the Epicauta cupraeola group from all other North American species of the genus Epicauta. The main structure of the key is a modification of Pinto's (1991) key for North American Epicauta, supplemented with photographic illustrations of the habitus of all species of the group.

1. Males without hind tibial comb. Eyes broadly emarginated, with a longer dorsal lobe. Antennal segment II shorter than half the length of III. Antennal segment I usually shorter than III, not impressed apically . subgenus Epicauta .... 2 


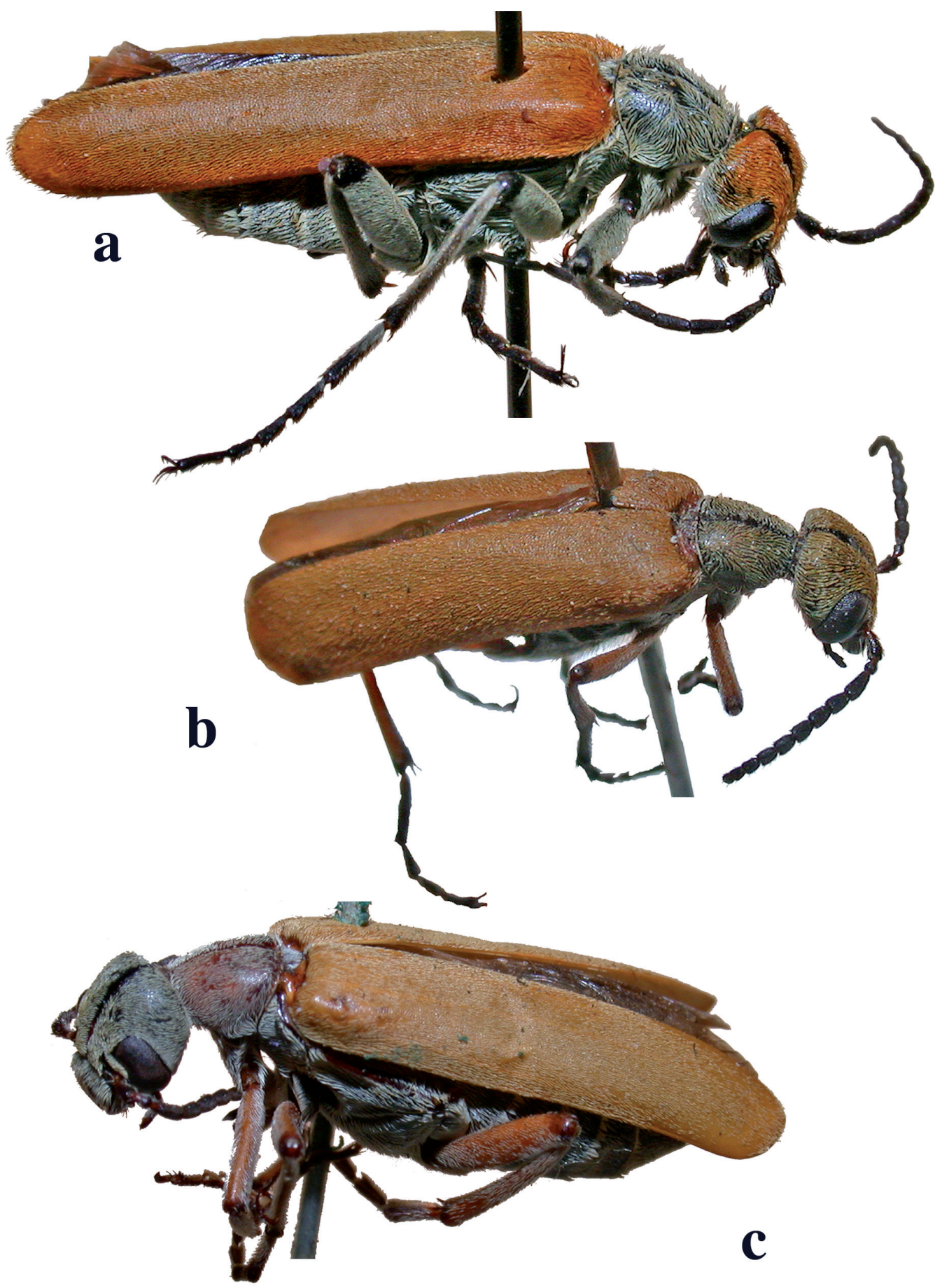

Fig. 3.- Habitus of species of the Epicauta cupraeola species group: a) Epicauta rufipennis (6 km Chilpancingo Omilteme, Guerrero, México); b) Epicauta diana (Acahuizotla, Guerrero, México); c) Epicauta diana (México).

Fig. 3.- Habitus de algunas especies del grupo de Epicauta cupraeola: a) Epicauta rufipennis (6 km Chilpancingo Omilteme, Guerrero, México); b) Epicauta diana (Acahuizotla, Guerrero, México); c) Epicauta diana (México). 
- Males with either: hind tibial comb present; eyes narrowly and deeply emarginated, with a longer ventral lobe; antennal segment II almost as long as or longer than III; antennal segment I much longer than III; or antennal segment I impressed or excavated apically .... subgenus Macrobasis

2. Male fore tibia with one spur at apex

$$
\text { E. cupraeola, E. maculata, and E. nigritarsis }
$$

species groups .... 3

- $\quad$ Fore tibia with two spurs at apex all other species groups

3. Cuticle of elytra and legs primarily orange-yellow, brown, or tan. Elytra non-maculate

E. cupraeola and E. nigritarsis species groups ... 4

- Cuticle of elytra and legs black. Elytra generally maculate ................................... E. maculata species group

4. Male antennal segment III slightly bowed with posterior surface concave and anterior surface convex. Antennal segment I from slightly to highly curved anteroapically forming an apical lip. Hind tibial spurs moderately broad, shorter than middle tibial spurs ...... E. cupraeola species group .... 5

- Male antennal segments I and III not modified. Hind tibial spurs narrow, elongate, subequal to middle tibial spurs E. nigritarsis species group

5. Cuticle of elytra yellow orange

- Elytra dark brown to black ... 6

6. Legs black

- Legs partly dark orange

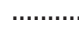

(1)... 7

7. Male antennal segment I distinctly inflated E. cora sp. nov. (Figs. 1a-d, 2a-c)

- Male antennal segment I linear, not inflated E. rufipennis (Fig. 3a)

8. Elytra with a distinct patch of black vestiture on humerus and adjacent to scutellum

E. basimacula (Fig. 4a)

- Elytra without a distinct patch of black vestiture on humerus or near scutellum

9

9. Male with segment I of middle tarsus inflated and distorted E. crassitarsis (Fig. 6a)

- Male with segment I of middle tarsus not inflated nor distorted 10

10. Pronotum and head densely, finely punctate; hind tibial spurs not abruptly broadened apically

- Pronotum and head densely, coarsely punctate; at least the outer hind tibial spur abruptly broadened apically, narrowly obliquely truncate .. 12

11. Male antenna distinctly ensiform; claws robust, broad, strongly curved E. tenebrosa (Fig. 6c)

- Male antenna not ensiform; claws slender, less curved E. pedalis (Fig. 6b)

12. Vestiture of elytra short, uniform and equally distributed; vestiture of head and pronotum not concealing underlying cuticle; eyes broad, moderately bulged ......

E. Ieucocoma (Fig. 4b)
- Vestiture of elytra denser and longer on margins; vestiture of head and pronotum longer, concealing underlying cuticle; eyes narrower, not as distinctly bulged ...... E. cupraeola (Fig. 5a-f)

\section{Phylogenetic relationships within the Epicauta cupraeola species group}

Pinto (1991) proposed a phylogenetic hypothesis for the species of the E. cupraeola group based on morphological characters. His analyses resulted in eight equally parsimonious trees. Pinto (1991: 238) selected the tree most consistent with overall similarity to depict a probable set of relationships. In this tree, E. rufipennis, the only species of the group known at that time with black leg cuticle, was placed as the sister taxon to all other taxa. The remaining species were distributed into two main clades: one comprised of E. basimacula and $E$. diana as sister taxa and the other comprised of the remaining species. This latter clade was subdivided into two subclades: one consisted of $E$. pedalis and E. tenebrosa, while a second subclade consisted of E. leucocoma as the sister taxon to an E. cupraeola - E. crassitarsis monophyletic group.

The discovery of E. cora, which shares many traits with both E. rufipennis and E. diana, and also with $E$. cupraeola, potentially challenged the previous hypothesis of relationships within the group. Unweighted Maximus Parsimony (MP) analyses resulted in 41 trees (Length $=23$; Consistency Index $=0.56$; Retention Index $=0.60)$. The resulting strict consensus tree shows a basal polytomy with a sister group relationship only between $E$. pedalis and $E$. tenebrosa. The phylogenetic hypothesis based on bootstrap analyses, including all groupings compatible with the $50 \%$ majority rule consensus tree (Fig. 7 ), is identical to the topology of the tree selected by Pinto (1991), but with the addition of E. cora as the sister taxon of E. rufipennis.

\section{Species composition of the Epicauta cupraeola group with additional comments}

The Epicauta cupraeola species group included eight species: E. basimacula (Haag-Rutenberg, 1880), E. crassitarsis Maydell, 1935, E. cupraeola (Dugès, 1869), E. diana Pinto, 1991, E. leucocoma Champion, 1892, E. pedalis LeConte, 1866, E. rufipennis (Chevrolat, 1834), and E. tenebrosa Werner, 1949. The current description adds a ninth 


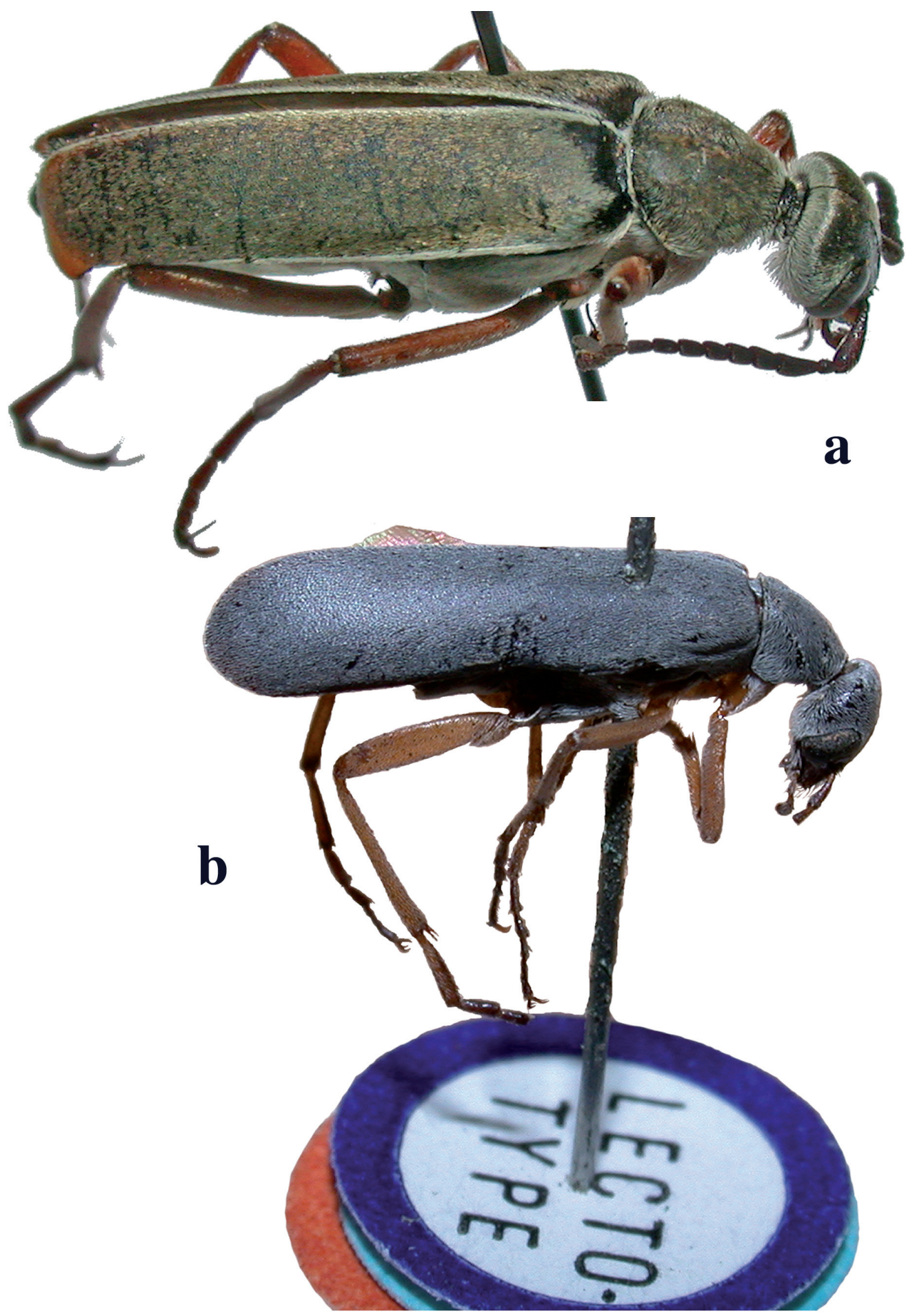

Fig. 4.- Habitus of species of the Epicauta cupraeola species group: a) Epicauta basimacula (7.5 km NE Juchitlán, Jalisco, México); b) Epicauta leucocoma (Tepanistlahuaca, México) (lectotype).

Fig. 4.- Habitus de algunas especies del grupo de Epicauta cupraeola: a) Epicauta basimacula (7.5 km NE Juchitlán, Jalisco, México); b) Epicauta leucocoma (Tepanistlahuaca, México) (lectotipo). 
species to the group: E. cora. The geographic distribution of this group is centered in Mexico, where all of these species are present, and four (E. diana, $E$. leucocoma, E. pedalis, and E. cora) are endemic. Pinto (1991) provided morphological descriptions, geographic ranges, and seasonal distributions, while García-París et al. (2007), provided a synonymic catalogue and geographic ranges in Mexico. The following taxonomic and geographic comments result from the study of the material indicated in Appendix I.

Epicauta (E.) basimacula was described from "Mexico" (original type locality according to Haag-Rutenberg, 1880), without further geographic information. As the type series was apparently lost, Pinto (1982) designated a lectotype in the Zoologische Staatssammlung (Munich). One year after the description of Cantharis basimacula, Dugès (1881) published the description of Cantharis rufescens from "Cotija". As the $C$. rufescens types were apparently lost, Pinto (1991), based on Dugès original description, considered $C$. rufescens as a synonym of E. basimacula. During our investigation, we found two syntypes of $C$. rufescens held at the CNIN-IBUNAM collection (see Appendix I). These specimens are consistent with the original description and allow confirmation of the synonymy proposed by Pinto (1991). The geographic range of E. basimacula extends from central Mexico to southwestern Guatemala (Pinto, 1991; García-París et al., 2007).

Epicauta (E.) crassitarsis was described from "Tempe, Ariz." (Maydell, 1935), and according to Pinto (1991), the holotype is in the collection of the United States National Museum of Natural History (Washington D.C.). Its geographic range extends from northwestern Mexico to southern Arizona (USA) (Pinto, 1991; García-París et al., 2007).

Epicauta (E.) cupraeola (Dugès, 1869) displays remarkable morphological and color pattern variation along its geographic range (Fig. 5a-e), thus generating the historical description of various taxa within its current geographic range. Pinto (1991) summarized all the variability and considered that all of the variants should be included within a single taxon; however, the within-area homogeneity and relatively well-defined geographical borders between morphological units, indicate some degree of incipient speciation. The location of the type localities suggests a complex pattern of interactions between morphological groups. García-París et al. (2007) provided a list of synonyms for the species. The type locality of Cantharis cupraeola was stated as "... cerros de Guanajuato" in the original description (Dugès, 1869), but it became "Guanajuato, Mexico" after designation of a neotype (Pinto, 1991). The neotype, held at the Natural History Museum (London), was examined (Fig. 5c). Two specimens identified by Vázquez \& Zaragoza (1979) as types of Cantharis cupraeola ( $\mathrm{n}^{\circ} 799$ of the CNINIBUNAM collection) from "Mirador, Ver." were also studied (Fig. 5d). However, as pointed out by Pinto (1991), the specimens from Veracruz were examined by Dugès after the original description and cannot be considered as type specimens of $C$. cupraeola (see also García-París et al., 2007). Pinto (1991) synonymized Cantharis rufipedes Dugès, 1870 (original type locality: "Michoacan, hacienda de la Noria...") and Cantharis cinctella Dugès, 1877 (original type locality: "Estado de Veracruz") with E. cupraeola after designation of the corresponding neotypes in the collection of the California Academy of Sciences (San Francisco, USA). However, the specimens from "Mirador, Ver." identified by Vázquez \& Zaragoza (1979) as types of C. cupraeola could be part of the original series used by Dugès (1870) for the description of C. cinctella. The problem is that Dugès (1870) did not specify a precise locality in the original description referring the provenance of specimens used with a reference to "Estado de Veracruz". In the collection of the Hungarian Natural History Museum in Budapest, there are two specimens from "Guanaxuato" [sic] labelled as paratypes of Cantharis cupraeola and Cantharis rufipedes respectively; these specimens cannot be types, because Dugès (1869) did not use the ancient spelling for Guanajuato (Guanaxuato) in his published work, and the type locality for C. rufipedes is in Michoacán (not in Guanajuato). Lytta subvittata Haag-Rutenberg, 1880 (a preoccupied name) was described from "Mexico", and a lectotype was designated by Pinto (1982) at the Museum Zoologicum Universitatis (Helsinki). We examined three paralectotypes preserved at the Natural History Museum (London) (Fig. 5e). The name Epicauta vittula Beauregard, 1889 was proposed to replace Lytta subvittata. The terra typica of 

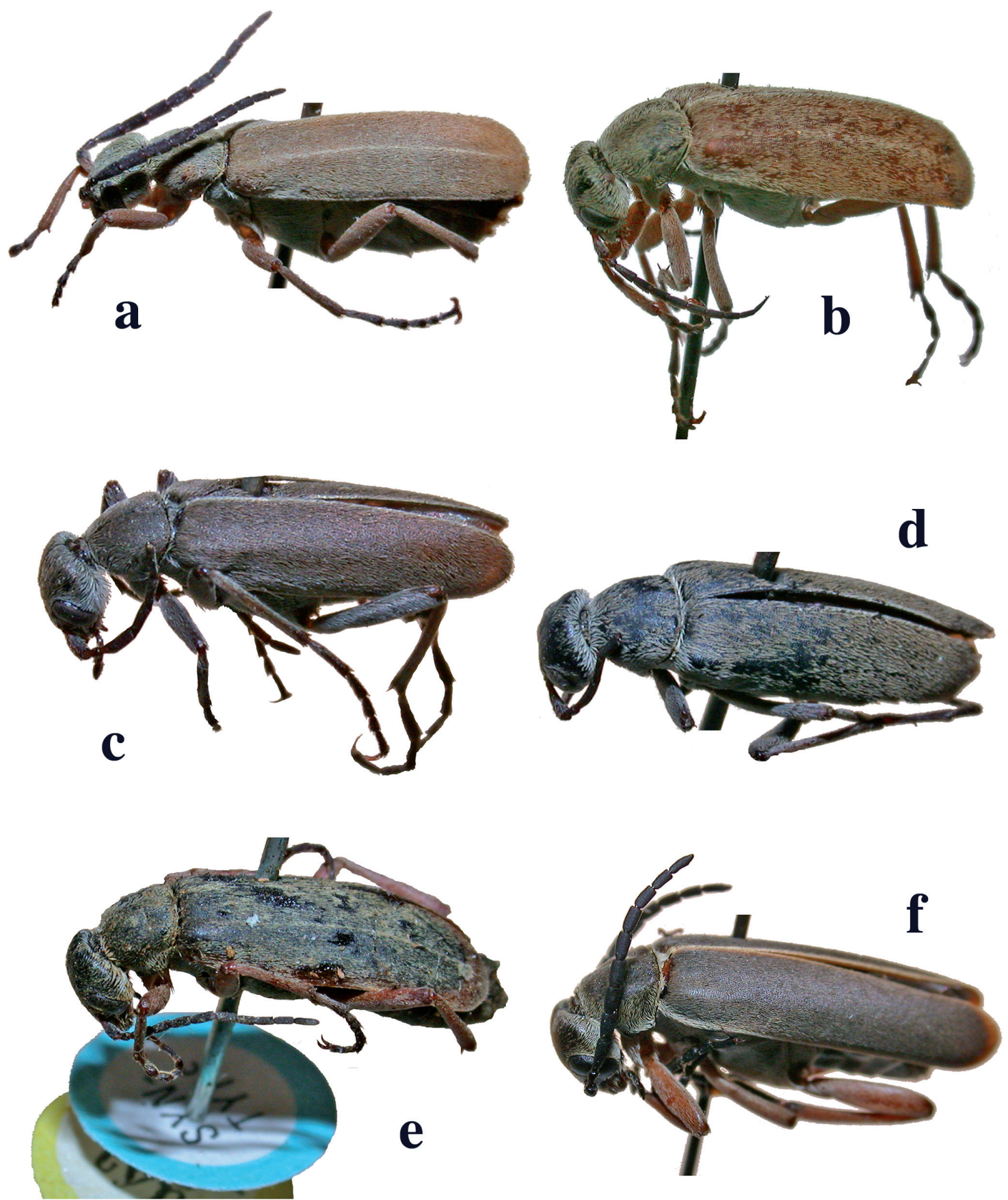

Fig. 5.- Habiti of specimens of Epicauta cupraeola representing its geographical diversity: a) Colima (Colima, México); b) Patagonia Mountains (Arizona, USA); c) Guanajuato (Guanajuato, México) (neotype of Cantharis cupraeola); d) Mirador [Huatusco] (Veracruz, México); e) [lzúcar de] Matamoros (Puebla, México) (paralectotype of Lytta subvittata); f) Calakmul, Km 78 carretera Escárcega - Xpuhil (Campeche, México).

Fig. 5.- Diversidad geográfica en el habitus de ejemplares de Epicauta cupraeola: a) Colima (Colima, México); b) Patagonia Mountains (Arizona, USA); c) Guanajuato (Guanajuato, México) (neotipo de Cantharis cupraeola); d) Mirador [Huatusco] (Veracruz, México); e) [lzúcar de] Matamoros (Puebla, México) (paralectotipo de Lytta subvittata); f) Calakmul, Km 78 carretera Escárcega - Xpuhil (Campeche, México). 


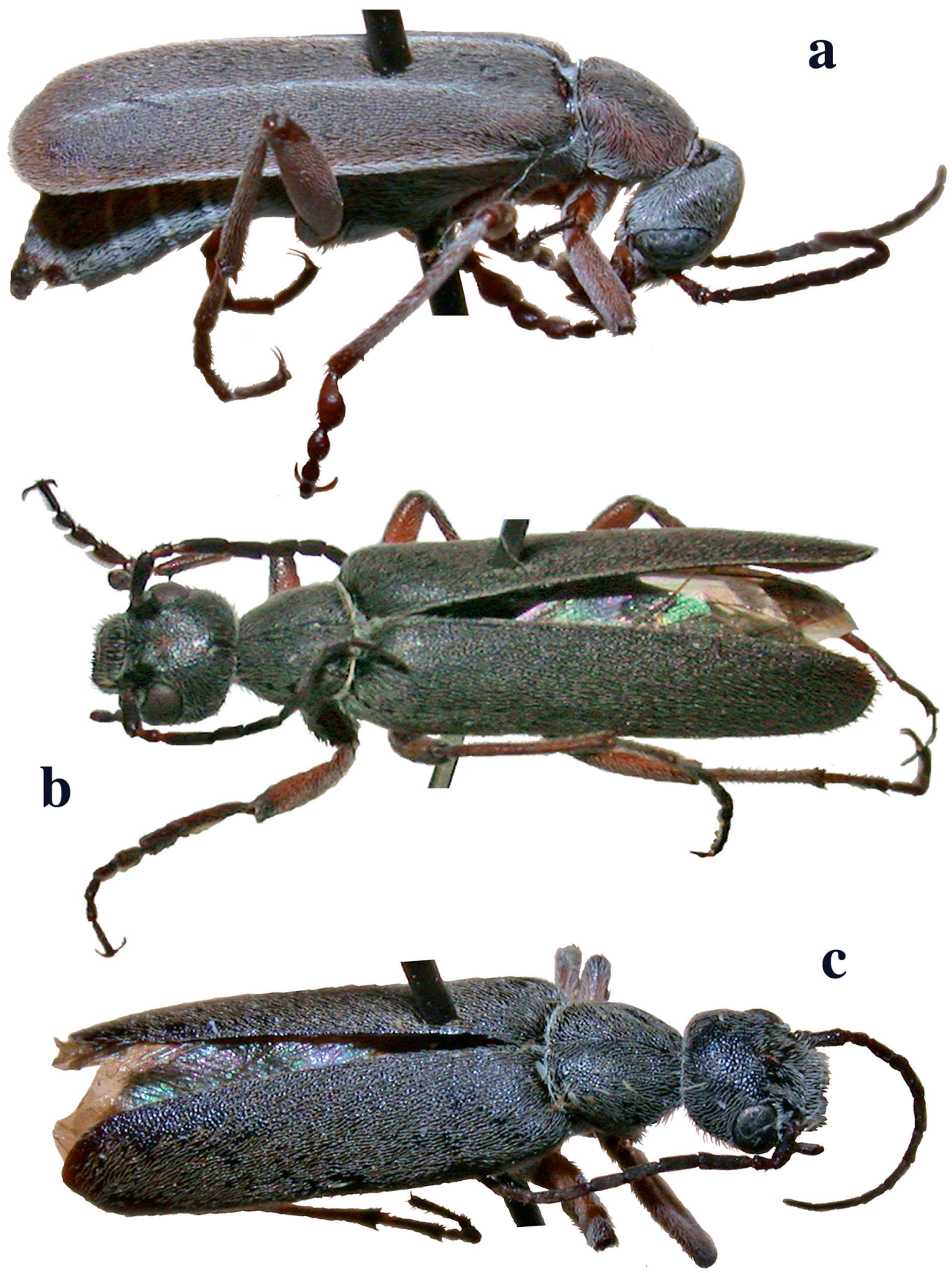

Fig. 6.- Habiti of species of the Epicauta cupraeola species group: a) Epicauta crassitarsis (Santa Rita Mountains, Arizona, USA); b) Epicauta pedalis (Bahía de Las Palmas, La Paz; Baja California Sur, México); c) Epicauta tenebrosa (Tucson, Arizona, USA) (paratype).

Fig. 6.- Habitus de especies del grupo de Epicauta cupraeola: a) Epicauta crassitarsis (Santa Rita Mountains, Arizona, USA); b) Epicauta pedalis (Bahía de Las Palmas, La Paz; Baja California Sur, México); c) Epicauta tenebrosa (Tucson, Arizona, USA) (paratipo). 


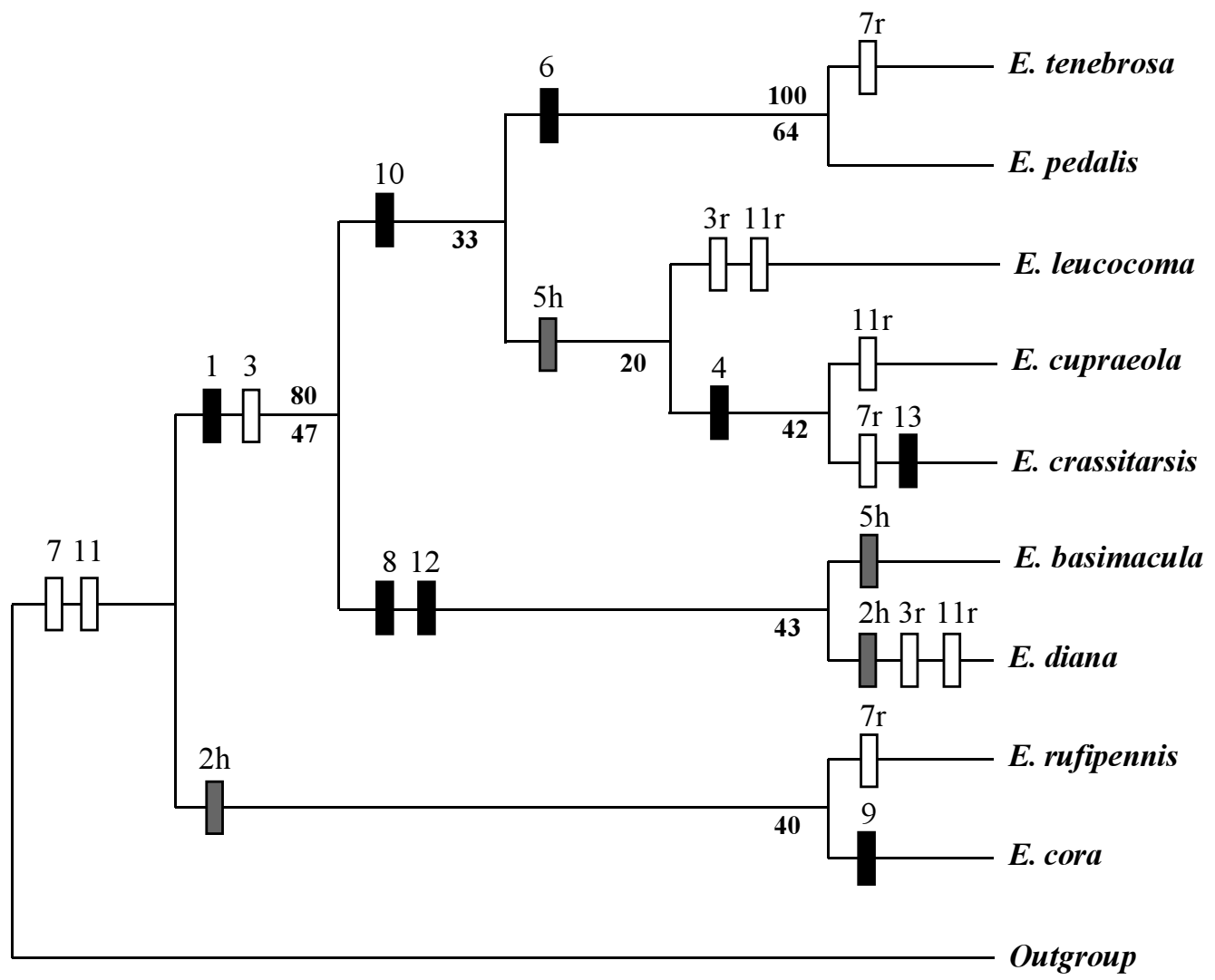

Fig. 7.- Consensus tree (50\% majority rule) of the two most parsimonious trees $(\mathrm{L}=31, \mathrm{Cl}=0.58, \mathrm{RI}=0.65)$, depicting phylogenetic relationships of the taxa of the Epicauta cupraeola species group. Numbers above branches indicate consensus percentage, numbers below branches indicate bootstrap support. Boxes, and the numbers above them, represent characters: solid black rectangles indicate synapomorphies; gray rectangles indicate homoplastic characters that evolved independently in two clades; white rectangles indicate characters that show reversals (also indicated by the letter " $r$ " after character number). Character numbers correspond to numbers in Appendix II.

Fig. 7.- Árbol de consenso (regla del 50\%) de los dos árboles más parsimoniosos $(\mathrm{L}=31, \mathrm{Cl}=0.58, \mathrm{RI}=0.65)$, que muestra las relaciones filogenéticas de los taxones del grupo de Epicauta cupraeola. Los números sobre las ramas indican el porcentaje de consenso, los números bajo las ramas indican el apoyo de "bootstrap". Los recuadros y los números sobre ellos indican caracteres: los recuadros negros indican sinapomorfías; los grises caracteres homoplásicos que han evolucionado independientemente en dos clados diferentes; los recuadros blancos indican caracteres con reversiones (también señalados con la letra " $r$ " tras el número del carácter). Los números de los caracteres corresponden a los indicados en el Apéndice II.

Epicauta insignis Horn, 1885, another synonym of E. cupraeola, is "Arizona", and a lectotype was designated by Werner (1945) at the Museum of Comparative Zoology (Harvard University, USA). The geographic range of E. cupraeola extends from Costa Rica to the southwestern USA, and includes Nicaragua, Honduras, El Salvador, Guatemala, and Mexico (Pinto, 1991; Maes \& Huether, 2007; García-París et al., 2007).
Epicauta (E.) diana is an endemic species of Mexico, described from "6 mi. E Villa Union, Sinaloa, Mexico" (Pinto, 1991). This species was previously known from Oaxaca, Sinaloa (Pinto, 1991; García-París et al., 2007) and Chiapas (García-París et al., 2009); based on this study, it is also now known from the state of Guerrero (Appendix I). 
Epicauta (E.) leucocoma was described from "Mexico, Tepanistlahuaca..., Acapulco" in the original description (Champion, 1892), but from “Tepanistalabuaca, Mexico, ..."(sic) after the lectotype designation (Pinto, 1982). The lectotype and four paralectotypes kept in the collection at the Natural History Museum (London) were examined (Fig. 4b). It is a Mexican endemic species, known from the states of Guerrero, Jalisco, and Oaxaca (Pinto, 1991; García-París et al., 2007).

Epicauta (E.) pedalis is a species endemic to Mexico, only known from Baja California Sur (Pinto, 1991; García-París et al., 2007). It was described from "Cape San Lucas, Lower California" (LeConte, 1866). The lectotype, designated by Werner (1945), is held in the collection at the Museum of Comparative Zoology (Harvard University, Cambridge, USA) (fide Pinto, 1991).

Epicauta (E.) rufipennis is a geographically variable species described from the "environs de Mexico" (Chevrolat, 1834). Its holotype, according to Pinto (1991), is possibly located in the collections at the Museum Zoologicum Universitatis (Helsinki). Cantharis ocreaceipennis Dugès, 1870, a synonym of E. rufipennis, was described from "...cercanías de Guanajuato", but the type is lost, as it was not found in the CNIN-IBUNAM collection. The type of Cantharis ochreipennis Dugès, 1877 from "Estado de Veracruz,... mineral de la Luz á algunas leguas de Guanajuato;... en uno de los paseos de esta última ciudad", is also lost, as it was also not found in the CNIN-IBUNAM collection. Pinto (1991) remarked that the vestiture of specimens from Jalisco, Nayarit, and Chihuahua differ morphologically from other populations. The species is distributed through Mexico and Guatemala (Pinto, 1991; García-París et al., 2007). In Mexico, the species was reported from the states of Chihuahua, Distrito Federal, Guanajuato, Guerrero, Hidalgo, Jalisco, México, Michoacán, Morelos, Nayarit, Oaxaca, Puebla, Sinaloa, Veracruz, and Chiapas (García-París et al., 2009).

Epicauta (E.) tenebrosa was described from "Tucson, Arizona" by Werner (1949). Its holotype is in the collection at the Museum of Comparative Zoology (Harvard University, Cambridge, USA) (Werner, 1949; Pinto, 1991). Four paratypes are located at the Natural History Museum of London, and two paratypes are located at the Museo del Instituto de Zoología Agrícola of Maracay; all six paratypes were examined (Fig. 6c). The species is distributed from northern Sonora (Mexico) to southern Arizona (USA) (Pinto, 1991; García-París et al., 2007).

\section{Acknowledgments}

Our work would have not been possible without the help of the curators of the scientific collections and researchers at the institutions visited: Alejandro Zaldívar (Instituto de Biología, UNAM, México DF), Weiping Xie (Natural History Museum of Los Angeles County), Jesús Manzanilla, Luis José Joly, and Hermes Escalona (Museo del Instituto de Zoología Agrícola, Maracay), Ötto Merkl and Judit Vörös (Magyar Természettudományi Múzeum, Budapest), and Max Barclay (Natural History Museum, London). We are especially grateful to Marco A. Bologna (Università Roma Tre) for letting us study his collection, and to John D. Pinto for exhaustive comments to an earlier version of the manuscript. Thanks to Melinda Modrell for language revision of the final copy. This work was supported by grant CGL2010-15786 from the Ministerio de Economia y Competitividad (Spain). MGP visit to the Instituto de Biologia (UNAM) was supported by the program "Estancias Libres" CSIC-UNAM (2010).

\section{References}

Adams, C. L. \& Selander, R. B., 1979. The biology of blister beetles of the Vittata group of the genus Epicauta (Coleoptera, Meloidae). Bulletin of the American Museum of Natural History, 162: 139-266.

Barrón Mayorquín, C. (coordinador). 2005. Enciclopedia de los Municipios de México. Instituto Nacional para el Federalismo y el Desarrollo Municipal, Gobierno del Estado de Nayarit (http://www.e-local.gob.mx/ work/templates/enciclo/nayarit/ mpios/18009a.htm) (consulted Dic-2008).

Beauregard, H., 1889. [Notes synonymiques]. Annales de la Société Entomologique de France, $6^{\mathrm{e} m}$ Série, 9 (Séance du 13 novembre 1889): ccxii-ccxiii.

Beauregard, H., 1890. Les insectes vésicants. Félix Alcan. París. i-xvi, 1-544, 34 láms.

Bologna, M. A. \& Pinto, J. D., 2002. The Old World genera of Meloidae (Coleoptera): a key and synopsis. Journal of Natural History, 36: 2013-2102.

Champion, G. C., 1892. Family Meloidae. In: F. E. Godman \& O. Salvin (eds.). Biologia CentraliAmericana. Coleoptera Heteromera, Vol. 4. pt. 2. London: 369-448, láms.: 17-21.

Champion, G. C., 1899. A list of the Cantharidae supplementary to the "Munich" Catalogue. Annales de la Société Entomologique de Belgique, 43: 153-207. 
Chevrolat, L. A. A., 1834. Coléoptères du Mexique. $4 e$. Fascicule. G. Silbermann. Strasbourg. [70] pp. Sin paginar.

Dugès, E., 1869a. Descripción de algunos meloideos indígenas. La Naturaleza, 1: 100-113.

Dugès, E., 1869b. Descripción de algunos meloideos indígenas. La Naturaleza, 1: 125-128.

Dugès, E., 1870. Descripción de algunos meloideos indígenas. La Naturaleza, 1: 161-171, láms. 1-2.

Dugès, E., 1877. Descripción de algunos meloideos indígenas. La Naturaleza, 4: 57-67, lám. 2.

Dugès, E., 1881. Descripción de algunos meloideos indígenas. La Naturaleza, 5: 140-148, lám. 4.

Dugès, E., 1886. Note pour servir a la classification des méloïdes du Mexique. Bulletin de la Societé Zoologique de France, 11: 578-582.

Erichson, W. F., 1848. Vol. 3. Die Insekten. In: R. Schomburgk. Reisen in Britisch-Guiana in den Jahren 1840-1844. J. J. Weber. Leipzig: 533-617.

García-París, M., Buckley, D. \& Parra-Olea, G., 2007. Catálogo taxonómico-geográfico de los coleópteros de la familia Meloidae de México. Graellsia, 63(2): 165-258. doi: 10.3989/graellsia.2007.v63.i2.92

García-París, M., Ruiz, J. L. Vörös, J. \& Parra-Olea, G., 2009. Sinopsis de los Meloidae (Coleoptera) de Chiapas (México) y comentarios sobre el género Denierota Kaszab, 1959. Graellsia, 65(1): 47-58. doi: 10.3989/graellsia.2009.v65.i1.134

Haag-Rutenberg, J. G., 1880. Beiträge zur Kentniss der Canthariden. Deutsche Entomologische Zeitschrift, 24: 17-90.

Horn, G. H., 1885. Studies among the Meloidae. Transactions of the American Entomological Society, 12: 107-116, lám. 5

LeConte, J. L., 1866. New species of North American Coleoptera. Prepared for the Smithsonian Institution. Smithsonian Miscellaneous Collections, 167: 87-177.

Maes, J. M. \& Huether, J. P., 2007. Catálogo ilustrado de los Meloidae (Coleoptera) de Nicaragua y otras especies contenidas en el Museo Entomológico de León. Revista Nicaragüense de Entomología, 67 (Suplemento 3): 1-90.

Maydell, G. G., 1935. A new species of blister beetle form Arizona. Journal of the Washington Academy of Sciencies, 25(2): 72.

Parra-Olea, G., García-París, M. \& Wake, D. B., 2004. Molecular diversification of salamanders of the tropical American genus Bolitoglossa (Caudata: Plethodontidae) and its evolutionary and biogeographical implications. Biological Journal of the Linnean Society, 81: 325-346.
Pinto, J. D., 1982. New synonymies, lectotype designations, and other notes on North American Epicauta (Coleoptera: Meloidae). Proceedings of the Entomological Society of Washington, 84(2): 402-408.

Pinto, J. D., 1991. The taxonomy of North American Epicauta (Coleoptera: Meloidae), with a revision of the nominate subgenus and a survey of courtship behavior. University of California Publications in Entomology, 110: i-x, 1-372, 40 láms.

Pinto, J. D. \& Bologna, M. A., 1999. The New World genera of Meloidae (Coleoptera): a key and synopsis. Journal of Natural History, 33: 569-620.

Swofford, D., 2002. "PAUP*: Phylogenetic analysis using parsimony (* and other Methods)", Version 4. Sinauer Associates. Sunderland, Massachusetts.

Vázquez, G. L. \& Zaragoza, C. S., 1979. Tipos existentes en la colección entomológica del Instituto de Biología, de la Universidad Nacional Autónoma de México. Anales del Instituto de Biología de la Universidad Nacional Autónoma de México, Serie Zoología, 50: 575-632.

Werner, F. G., 1945. A revision of the genus Epicauta in America north of Mexico. Bulletin of the Museum of Comparative Zoology at Harvard College, 95: 421531.

Werner, F. G., 1949. Additions to Epicauta, with new synonymy and change of names (Coleoptera: Meloidae). Psyche, 56(3): 93-111.

Werner, F. G., 1954. A review of the subgenus Gnathospasta of the genus Epicauta (Meloidae). The Coleopterists'Bulletin, 8: 25-27. 
Appendix I.- Material examined of the Epicauta cupraeola species group. The acronyms used are as follows: CNINIBUNAM: Colección Nacional de Insectos of the Instituto de Biología of the Universidad Nacional Autónoma de México (Mexico); NHMLA: Natural History Museum of Los Angeles County, California (USA); MAB: M. A. Bologna collection at Roma Tre University, Roma (Italy); MIZA: Museo del Instituto de Zoología Agrícola of the Universidad Central de Venezuela, Maracay (Venezuela); HNHM: Hungarian Natural History Museum (Magyar Természettudományi Múzeum) of Budapest (Hungary), and BMNH: Natural History Museum of London (UK).

Apéndice I.- Material examinado del grupo de especies de Epicauta cupraeola. Los acrónimos utilizados son: CNINIBUNAM: Colección Nacional de Insectos del Instituto de Biología de la Universidad Nacional Autónoma de México (México); NHMLA: Natural History Museum of Los Angeles County, California (USA); MAB: collección de M. A. Bologna en Roma Tre University, Roma (Italy); MIZA: Museo del Instituto de Zoología Agrícola de la Universidad Central de Venezuela, Maracay (Venezuela); HNHM: Hungarian Natural History Museum (Magyar Természettudományi Múzeum) de Budapest (Hungria), y BMNH: Natural History Museum de Londres (UK).

\section{Epicauta (Epicauta) basimacula (Haag-Rutenberg, 1880)}

TYPE SPECIMENS: Syntypes of Cantharis rufescens (2 specimens) [CNIN-IBUNAM]: Cotija, Michoacán / 750 / Col. E. Dugès

Non type Material: México: 1 specimen (2310) (Sallé Coll.) (Epicauta basimacula Haag) [country record] [BMNH]. Colima: Colima: VII, 1 specimen (C.C. Hoffmann) [CNIN-IBUNAM]; XII-1915, 2 specimens (C.C. Hoffmann) [CNIN-IBUNAM]. Guerrero: Iguala: 1 specimen (Höge) (Godman - Salvin Coll., Biol. Centr.-Amer.) (Sp. figured) (Epicauta basimacula Haag = rufescens Dugès) (Epicauta basimacula Haag det. F. Werner) (Epicauta basimacula Haag M.J.D. Brendell 1980) (BM) (Epicauta basimacula (Haag) det. J.D. Pinto 1987) [BMNH]; Iguala: 4 specimens (Höge) (Godman - Salvin Coll., Biol. Centr.Amer.) (Epicauta basimacula Haag) [BMNH]; Iguala: 7 specimens (Höge) (Godman - Salvin Coll., Biol. Centr.-Amer.) (BM) (Epicauta basimacula (Haag) det. J.D. Pinto 1987) [BMNH]; Iguala: 3 specimens (Höge) (Godman - Salvin Coll., Biol. Centr.Amer.) [BMNH]; 4 km E Mezcala: 26-VI-1971, 1 specimen (E. Martín F.) (Epicauta basimacula (Haag-R.), J. D. Pinto det., 1987/8) [CNIN-IBUNAM]. Jalisco: 1 specimen (Fry Coll. 1905100) (BM) (Epicauta basimacula (Haag) det. J.D. Pinto 1987) [BMNH]; 1 specimen (28590) (Fry Coll. 1905-100) (BM) (Epicauta basimacula (Haag) det. J.D. Pinto 1987) [BMNH]; Loc. 3, Arroyo Los Yesos: 4-VI-1997, 1 specimen (S. Zaragoza) [CNIN-IBUNAM]; 7.5 km NE Juchitlán: 15-VII-1981, 1 specimen, on Prosopis (J. Mathieu, E. Fisher \& J. LaSalle leg.) (Epicauta basimacula (Haag-R.), J.D. Pinto det.) [MAB] (Fig. 4a). México: Temescaltepec: Bejucos, ca. 2000 ft.: VII-1953, 1 specimen (H.E. Hinton \& R.L. Usinger leg.) (BM) (B.M. 1959.100) (Epicauta basimacula (Haag) det. J.D. Pinto 1987/8) [BMNH]. Michoacán: Cotija: 2 specimens (Col. E. Dugès, 750) [CNIN-IBUNAM] [Syntypes of Cantharis rufescens Dugès, 1881]. Nayarit: Las Sabinas: 8-VII-1991, 2 specimens (R. Barba, E. Barrera) [CNIN-IBUNAM]; Río Huaynamota, Los Sabinos: 8 al 11-VII-1991, 3 specimens (E. Barrera, R. Barba) [CNINIBUNAM]; Río Santiago, Playa Golondrinas, El Nayar: 15-VII1991, 2 specimens (E. Barrera, R. Barba) [CNIN-IBUNAM]. Oaxaca: Tehuantepec: 1 specimen (Mexico Sallé Coll.) (Epicauta basimacula Haag) [BMNH].

\section{Epicauta (Epicauta) cora García-París et Ruiz sp. nov.}

TYPE SPECIMENS: Holotype of Epicauta cora [CNIN-IBUNAM] (Figs. 1a-d, 2): MÉXICO: NAYARIT: Río Huaynamota, Los Sabinos: 8/11-VI-1991 (R. Barba, E. Barrera leg.).

\section{Epicauta (Epicauta) crassitarsis Maydell, 1935}

Non tyPe Material: MéXico: Sinaloa: 57 mi. N Culiacán: 28VIII-1959, 2 specimens (Stange; Menke) (Epicauta crassitarsis Maydell, J. D. Pinto det., 1987/8) [NHMLA]. Sonora: Álamos: 25-VII/7-VIII-1953, 1 specimen (F. S. Truxal) (Epicauta crassitarsis Maydell, R. B. Selander det., 1942) [NHMLA].

USA: Arizona: Bavoquivari Canyon, W slope Bavoquivari Mountains, 3000 ft.: 17-VII-1949, 1 specimen, oak-hackberry zone (W. Nutting \& F. Werner leg.) (E. crassitarsis, F.G. Werner Collection) (E. crassitaris Maydell, F. Werner det.) [MIZA]; Phoenix: 11-VIII-51, 1 specimen (Epicauta crassitarsis Maydell det. R.B. Selander 1953) [HNHM]; Phoenix: 8-VII-1951, 1 specimen, at light (Y. Sedman leg.) (Brit. Mus. 1952-531) (Epicauta crassitarsis Maydell Det. R.B. Selander '57) [BMNH]; Phoenix: 8-VII-1951, 2 specimens, at light (Y. Sedman leg.) (Brit. Mus. 1952-531) [BMNH]; Phoenix 15-VIII51, 3 specimens (Y. Sedman leg.) (Epicauta crassitarsis Maydell, 1935 det. Kaszab 1953) [HNHM]; Phoenix: 13-VII1947, 1 specimen, 1t. [at light] (F. Werner leg.) (Brit. Mus. 1951.629) (Epicauta crassitarsis Maydell det. F.G. Werner) [BMNH]; Phoenix: 13-VII-1947, 1 specimen, lt. [at light] (F. Werner leg.) (Brit. Mus. 1951.629) [BMNH]; Santa Rita Mts.: 31-VII-1941, 1 specimen (F.H. Parker) (Epicauta crassitarsis Maydell, det. F. Werner) [BMNH] (Fig. 6a); Santa Cruz Co.: Río Rico: VII-1978, 1 specimen (Lenczy leg.) (M.A. Bologna det.) [MAB]; Tempe: 8-VII-1947, 1 specimen, lt. [at light] (F. Werner leg.) (Epicauta crassitarsis Maydell F.G. Werner Collection) [BMNH]; Tempe: 18-VII-1967, 1 specimen, at light (F. Werner leg.) (E. crassitarsis, F.G. Werner Collection) [MIZA].

\section{Epicauta (Epicauta) cupraeola (Dugès, 1869)}

TYPE SPECIMENS: Neotype of Cantharis cupraeola [BMNH] (Fig. 5c): Mexico. Salle Coll. / Guanajauto / Godman - Salvin Coll., Biol. Centr.-Amer. / Cantharis cupreola Dugès apud Sallé / B.M. / Neotype Cantharis cupraeola Dugès, desig. J.D. Pinto, 1987 [1991].

Paralectotypes of Lytta subvittata (3) [BMNH] (Fig. 5e): Syntype / Paratype / Matamoras [sic] / F. Bates 81-19 / subvittata typ Haag / subvittata Haag / Syntype Epicauta subvittata Haag = rufipedes (Dug.) M.J.D. Brendell 1980

Non type MAterial: Costa Rica: 1 specimen (91.65) (Epicauta cupraeola Dugès det. J.D. Pinto 1987/8) (BM) [country record] [BMNH]. Guanacaste: VI-1890, 2 specimens 
(H. Pittier leg.) (Epicauta cupraeola Dugès det. J.D. Pinto 1987/8) (BM) [BMNH].

Guatemala: S. [San] Gerónimo: 2 specimens (Champion) (Godman - Salvin Coll., Biol. Centr.-Amer.) (Epicauta rufipedes Dugès) (BM) (Epicauta cupraeola Dugès det. J.D. Pinto 1987/8) [BMNH].

Honduras: 1 specimen (123) (BM) (Epicauta cupraeola Dugès det. J.D. Pinto 1987) [BMNH].

MÉXICO: 1 specimen (22964) (Truqui) (Fry Coll. 1905100) (BM) (Epicauta cupraeola Dugès det. J.D. Pinto 1987/8) [BMNH]; 1 specimen (22964) (Truqui) (Fry Coll. 1905-100) (BM) (Epicauta rufipedes Dugès R.B. Selander det. 1954) (Epicauta cupraeola Dugès det. J.D. Pinto 1987/8) [BMNH]; 1 specimen (80.29) (Epicauta cupraeola Dugès det. J.D. Pinto 1987) [BMNH]; 1 specimen (83.29) (BM) (Epicauta cupraeola Dugès det. J.D. Pinto 1987/8) [BMNH]; 1 specimen (cinctella Dugès t. Haag) (cinctella Dugès) (F. Bates 81-19) (Epicauta cupraeola Dugès det. J.D. Pinto 1987/8) (BM) [BMNH]; 1 specimen (dilaticornis Chev. Mexique) (cinctella Dugès t. Haag) (cinctella Dugès) (F. Bates 81-19) (Epicauta cupraeola Dugès det. J.D. Pinto 1987/8) (BM) [BMNH]; 1 specimen (Epicauta cinctella Dug.) (BM) (Epicauta cupraeola Dugès det. J.D. Pinto 1987) [BMNH] [without head]; 1 specimen (Epicauta cinctella) (Nevinson Coll. 1918.14) (BM) (Epicauta cupraeola Dugès det. J.D. Pinto 1987/8) [BMNH]; 1 specimen (Epicauta cinctella) (Nevinson Coll. 1918.14) (BM) [BMNH]; 1 specimen (Ichicant [?]) (Fry Coll. 1905-100) (BM) (Epicauta cupraeola Dugès det. J.D. Pinto 1987/8) [BMNH]; 1 specimen (Lytta) (BM) (Epicauta cupraeola Dugès det. J.D. Pinto 1987) [BMNH]; 2 specimens (cinctella Dugès t. Haag) (cinctella Dugès) (F. Bates 81-19) (BM) [BMNH]; 3 specimens (Truqui) (Fry Coll. 1905-100) (BM) (Epicauta cupraeola Dugès det. J.D. Pinto 1987/8) [BMNH]. Campeche: Calakmul, Km 78 carretera Escárcega - Xpuhil: 31-V-2001, 1 specimen (L. Cervantes, C. Mayorga) [CNINIBUNAM] (Fig. 5f). Chiapas: VI, 1 specimen (C.C. Hoffmann) / Epicauta cupraeola (Dugès), J. D. Pinto det., 1987/8 [CNIN-IBUNAM]; Cascada de Agua Azul, Km 80 carretera Palenque - Bonampak (E. Barrera) [CNIN-IBUNAM]; Tapachula: 1 specimen (Höge (Godman - Salvin Coll., Biol. Centr.-Amer.) (Epicauta rufipedes Dugès female) (BM) (Epicauta cupraeola Dugès det. J.D. Pinto 1987/8) [BMNH]. Colima: Colima: VI, 1 specimen (C.C. Hoffmann) / Epicauta cupraeola (Dugès), J. D. Pinto det., 1987/8 [CNIN-IBUNAM] (Fig. 5a); VII, 9 specimens (C.C. Hoffmann) [CNINIBUNAM]; VII-1915, 1 specimen (C.C. Hoffmann) [CNINIBUNAM]; VIII-1916, 20 specimens (C.C. Hoffmann, 015) [CNIN-IBUNAM]; VII, 3 specimens (C.C. Hoffmann, 814) / Epicauta cupraeola (Dugès), J. D. Pinto det., 1987/8 [CNINIBUNAM]. Durango: 4 mi. S Casco, 5800 ft.: 16-VI-1960, 1 specimen (R.A. Schreibner leg.) (E. rufipedes F.G. Werner Collection) [MIZA]. Guanajuato: Guanajuato: 1 specimen (Salle Coll.) (Godman - Salvin Coll., Biol. Centr.-Amer.) (Cantharis cupreola Dugès apud Sallé) (2334) [BMNH]; Guanajuato: 2 specimens (Salle Coll.) (Godman - Salvin Coll., Biol. Centr.-Amer.) (Cantharis cupreola Dugès apud Sallé) [BMNH]; Guanajuato: 1 specimen (Mexico Sallé Coll.) (Cantharis cupreola Dugès ... apud Sallé) (Godman - Salvin Coll., Biol. Centr.-Amer.) (Epicauta cupraeola (Dugès) M.J.D. Brendell, 1980) [BMNH]; Guanajuato: 1 specimen (Mexico Sallé Coll.) (Cantharis cupreola Dugès ... apud Sallé) (Godman - Salvin Coll., Biol. Centr.-Amer.) (Epicauta cuprae- ola F. Dugès Werner det.) [BMNH]; Guanajuato: 3 specimens (Mexico Sallé Coll.) (Cantharis cupreola Dugès ... apud Sallé) (Godman - Salvin Coll., Biol. Centr.-Amer.) [BMNH]; Guanaxuato [sic] [print; green label]: 1 specimen (E. Dugès) [print; green label] (Paratypus 1869 Cantharis cupraeola Dugès) [handwritten in part; white label with red margins] [HNHM] [see comments about this specimen in the text]; Guanaxuato [sic] [print; green label]: 1 specimen (E. Dugès) [print; green label] (Paratypus 1869 Cantharis rufipedes Dugès) [handwritten in part; white label with red margins] [HNHM] [see comments about this specimen in the text]. Guerrero: Altamirano: 15-IX-1952, 3 specimens [CNINIBUNAM]; Amula, 6000 ft: Sept, 1 specimen (H.H. Smith) (Godman - Salvin Coll., Biol. Centr-Amer.) (Epicauta rufipedes Dugès male) (Epicauta rufipedes Dugès det. F. Werner) (Epicauta cupraeola Dugès det. J.D. Pinto 1987/8) [BMNH]; Chilpancingo: 1 specimen (Höge) (BM) (Godman - Salvin Coll., Biol. Centr.-Amer.) (Cantharis cupreola Dugès) (Epicauta cupraeola Dugès det. J.D. Pinto 1987/8) [BMNH]; Chilpancingo: 1 specimen (Höge) (Godman - Salvin Coll., Biol. Centr.-Amer.) (BM) (Epicauta cupraeola Dugès det. J.D. Pinto 1987/8) [BMNH]; El Caracol: 18-VI-1987, 1 specimen (E. Barrera) [CNIN-IBUNAM]; Iguala: 3 specimens (Höge) (Godman - Salvin Coll., Biol. Centr.-Amer.) (BM) (Epicauta cupraeola Dugès det. J.D. Pinto) [BMNH]; Julio Blanco: 15VIII-1976, 2 specimens, bajo piedras (J. Hendrichs S.) [CNINIBUNAM]; 5 mi NNE Mexicala [sic], 2000 ft.: 31-VIII-1952, 2 specimens (R.B. Selander leg.) (Brit. Mus. 1953-792) (Epicauta rufipedes (Dugès) det. R.B. Selander 1953) (Epicauta cupraeola Dugès det. J.D. Pinto 1987/8) (BM) [BMNH]; Rincón, 2800 ft.: Sept, 1 specimen (H.H. Smith) (Godman - Salvin Coll., Biol. Centr.-Amer.) (Epicauta cupraeola Dugès det. J.D. Pinto 1987/8) [BMNH]; San Marcos, Llano Grande, 271 msnm, 16055'43"N-99'26'12"W: 20-IX-2005, 2 specimens (L. Cervantes, R. Carranza) [CNIN-IBUNAM]; Xochihuehuetlan Tehuaxtitlán, $1183 \mathrm{msnm}, 17^{\circ} 50^{\prime} 29^{\prime}$ 'N98031'21"W: 27-VIII-2005, 1 specimen (L. Cervantes, R. Carranza) [CNIN-IBUNAM]; Zumpango del Río, km 6.5 desv. a Filo de Caballo, 906 msnm, 78047'38'N-99³4'47'W: 25VIII-2005, 2 specimens (L. Cervantes, R. Carranza) [CNINIBUNAM]. Michoacán: 5 mi. SW Tiquicheo, $1400 \mathrm{ft}$.: 8-VII-1970, 1 specimen (E. Fisher; P. Sullivan) (Epicauta cupraeola (Dugès), J. D. Pinto det., 1987/8) [NHMLA]; Nueva Italia, $62 \mathrm{~km}$ S Uruapan, $1500 \mathrm{ft} .:$ 1-VIII-1952, 1 specimen, in flight (F. Werner leg.) (E. rufipedes F.G. Werner Collection) (E. rufipedes Dugès, F. Werner det.) [MIZA]. Morelos: Cuernavaca: 1 specimen [CNIN-IBUNAM]; Cuernavaca: 1VI-1974, 1 specimen (R. Medellín) [CNIN-IBUNAM]; Cuernavaca: 1 specimen (Sallé Coll.) (BM) (Godman - Salvin Coll., Biol. Centr.-Amer.) (Epicauta rufipedes Dugès, 1869 apud Sallé) (Epicauta rufipedes Dugès det. F. Werner) (Epicauta cupraeola Dugès det. J.D. Pinto 1987/8) [BMNH]; Km 67 Cuernavaca - Taxco: 17-VI-1987, 1 specimen $(\mathrm{H}$. Brailovsky) [CNIN-IBUNAM]; Tepaltzingo: 18-X-2002, 2 specimens (H. Brailovsky, E. Barrera) [CNIN-IBUNAM]; Xochitepec: 21-V-65, 1 specimen, ans Licht (J. Hendrichs S.) [CNIN-IBUNAM]. Oaxaca: Km 2 desviación Santo Domingo de Morelos, Km 178 carretera Puerto Angel - Puerto Escondido: 8-VI-2004, 7 specimens (E. Mariño) [CNINIBUNAM]; Km 14 carretera Huajuapan de León - Tehuacán: 15-VIII-1992, 2 specimens (E. Barrera, C. Mayorga) [CNINIBUNAM]; Km 28 Huajuapan - Juxtlahuaca: 1-IX-1990, 3 
specimens (E. Barrera, A. Cadena) [CNIN-IBUNAM]; Huajuapan de León: 17-IX-1980, 3 specimens (H. Brailovsky) [CNIN-IBUNAM]; 2 km al SO de El Camarón: 12-VII-2000, 1 specimen (A. Ibarra, C. Mayorga, E. Barrera) [CNINIBUNAM]; Oaxaca: 1 specimen (Hoege) (BM) (Godman Salvin Coll., Biol. Centr.-Amer.) (Epicauta rufipedes Dugès) (Epicauta cupraeola Dugès det. J.D. Pinto 1987) [BMNH]; Oaxaca: 2 specimens (Hoege) (BM) (Godman - Salvin Coll., Biol. Centr.-Amer.) (Epicauta rufipedes Dugès var. subvittata Haag) (Epicauta cupraeola Dugès det. J.D. Pinto 1987) [BMNH]; Tehuantepec: 1 specimen (Sallé Coll.) (Epicauta cupraeola Dugès det. J.D. Pinto 1987/8) (BM) [BMNH]; Totolapan, 16039'52'N-96¹6'75'O: 30-VI-1996, 1 specimen (H. Brailovsky, E. Barrera) [CNIN-IBUNAM]. Puebla: Atlixco - La Trinidad: 29-V-1994, 4 specimens (H. Brailovsky, E. Barrera) [CNIN-IBUNAM]; Izucar: 1 specimen (Sallé Coll.) (Godman - Salvin Coll., Biol. Centr.-Amer.) (Epicauta rufipedes Dugès, 1869 apud Sallé) (Epicauta rufipedes Dugès det. F. Werner) (Epicauta cupraeola Dugès det. J.D. Pinto 1987/8) [BMNH]; Tehuacán: X-1917, 1 specimen (C.C. Hoffmann) / Epicauta cupraeola (Dugès), J. D. Pinto det., 1987/8 [CNIN-IBUNAM]; 13 km carr. Tehuitzingo - Tlapa, 1150 m: 21-IX-2003, 9 specimens (H. Brailovsky, E. Barrera) [CNIN-IBUNAM]; 6 km N Tehuitzingo: 28-VI-1996, 1 specimen (H. Brailovsky, E. Barrera) [CNIN-IBUNAM]; 7 mi. NW Tehuitzingo, $4000 \mathrm{ft}$.: 1-IX-1970, 1 specimen (E. M. Fisher; J. L. Fisher) (Epicauta cupraeola (Dugès), J. D. Pinto det., 1987/8) [NHMLA]; Zapotitlán de las Salinas, 18¹9'56"N97³0'32”O: 4-VII-1996, 3 specimens (H. Brailovsky, E. Barrera) [CNIN-IBUNAM]. Quintana Roo: Playa Aventuras: 8-VII-1981, 2 specimens (Pech) [CNIN-IBUNAM]. Sinaloa: $3.2 \mathrm{~km}$ al S de Rosario: 1-IX-1976, 2 specimens (C. D. George; R. R. Snelling) (Epicauta cupraeola (Dugès), J. D. Pinto det., 1987/8) [NHMLA]. Veracruz: Jalapa: 2 specimens (Höge) (BM) (Godman - Salvin Coll., Biol. Centr.-Amer.) (Cantharis cupreola Dugès) (Epicauta cupraeola Dugès det. J.D. Pinto 1987/8) [BMNH]; Mirador [Huatusco]: 2 specimens (Colección E. Dugès 953, 2-799) [CNIN-IBUNAM] [specimens referred by Vázquez \& Zaragoza (1979) as types of $C$. cupraeola] (Fig. 5d); [San Andrés] Tuxtla: 1 specimen (Sallé Coll.) (Cantharis cinctella Dugès ... apud Sallé) (Godman Salvin Coll., Biol. Centr.-Amer.) (Epicauta rufipedes Dug. var. cinctella Dug. female) (Epicauta cupraeola Dugès det. J.D. Pinto 1987/8) (BM) [BMNH]; [San Andrés] Tuxtla: 2 specimens (Sallé Coll.) (Cantharis cinctella Dugès ... apud Sallé) (Godman - Salvin Coll., Biol. Centr.-Amer.) (Epicauta cupraeola Dugès det. J.D. Pinto 1987/8) (BM) [BMNH]; Zongolica: 28-V-1942, 1 specimen (L. Vásquez) [CNIN-IBUNAM]. Yucatán: Cuncunul, 200 ft., 20³8'321'N-88¹9'134"O: 13IX-1994, 4 specimens (E. Barrera) [CNIN-IBUNAM]; Temax N.: 1 specimen (Gaumer) (Godman - Salvin Coll., Biol. Centr.Amer.) (BM) (Epicauta rufipedes Dugès R.B. Selander det. 1954) (Epicauta cupraeola Dugès det. J.D. Pinto 1987/8) [BMNH]: Temax N.: 3 specimens (Gaumer) (Godman - Salvin Coll., Biol. Centr.-Amer.) (BM) (Epicauta cupraeola Dugès det. J.D. Pinto 1987/8) [BMNH].

NiCARAGUA: Chontales: 1 specimen (Janson) (Godman Salvin Coll., Biol. Centr.-Amer.) (Epicauta cupraeola Dugès det. J.D. Pinto 1987/8) (BM) [BMNH]; Granada: Domitila Wildlife Reserve, tropical dry forest, $11^{\circ} 57^{\prime} \mathrm{N}-85^{\circ} 46^{\prime} \mathrm{W}$ : 9/14VI-2007, 2 specimens, at light (O. Merkl, N. Bálint \& T. Németh leg.) [HNHM]
USA: Arizona: Patagonia: 30-VII-1941, 1 specimen (F.H. Parker) (Epicauta insignis Horn, male, F. Werner det.) [BMNH] (Fig. 5b); Patagonia Mountain: 30-VII-1941, 2 specimens (F.H. Parker leg.) (F.H. Parker Collection) (E. insignis Horn, F. Werner det.) [MIZA]; Cochise Co.: Pinery Canyon, 0.6 mi. W National Forest Line: 21-VII-1976, 1 specimen, on Prosopis (J.D. Pinto leg.) (J.D. Pinto det., 1987) [MAB]; Pima Co.: 8 mi N Sonoita: 21-VII-1940, 2 specimens, dry grassland (F. Werner \& W. Nutting leg.) (insignis Horn det. Werner '54) [HNHM]; Pima Co.: Madera Cn.: IX-1979, 4 specimens (Lenczy leg.) (Epicauta insignis Horn det., coll. Dr. R. Lenczy) [HNHM]Santa Cruz Co.: Oro Blanco Mountains: Peña Blanca Canyon: 6-VIII-1960, 1 specimen (L. M. Martin) (Epicauta insignis, J. D. Pinto det., 1972) [NHMLA].

No locality data: 1 specimen (167) (BM) (Epicauta cupraeola Dugès det. J.D. Pinto 1987) [BMNH]; 1 specimen (4749) (BM) (Epicauta cupraeola Dugès det. J.D. Pinto 1987) [BMNH]; 1 specimen (Nevinson Coll. 1918.14) (BM) (Epicauta cupraeola Dugès det. J.D. Pinto 1987/8) [BMNH].

\section{Epicauta (Epicauta) diana Pinto, 1991}

Non type Material: MéXICO: (85-21) (Epicauta diana Pinto, det J.D. Pinto, 1987; studied by author at time of description) [country record] [BMNH] (Fig. 3c). Chiapas: Berriozabal: 12/20-V-94, 1 specimen (C. Beutelspacher) [CNIN-IBUNAM]. Guerrero: Acahuixotla [Acahuizotla]: 4-V-82, 1 specimen $(\mathrm{H}$. Brailovsky) [CNIN-IBUNAM] (Fig. 3b).

\section{Epicauta (Epicauta) leucocoma Champion, 1892}

TYPE SPECIMENS: Lectotype of Epicauta leucocoma [BMNH] (Fig. 4b): Lectotype / Syntype / Tepanistlahuaca, Mexico. Salle Coll. / Godman - Salvin Coll., Biol. Centr.-Amer. / Epicauta leucocoma Ch. male / Sp. figured / Epicauta leucocoma M.J.D. Brendell, 1980 / Lectotype male Epicauta leucocoma Champ., desig. J.D. Pinto, 1981 [1982]

Paralectotype of Epicauta leucocoma [BMNH]: Paralectotype / Syntype / Tepanistlahuaca, Mexico. Salle Coll. / Godman Salvin Coll., Biol. Centr.-Amer. / Epicauta leucocoma Champion, det. F. Werner / Paralectotype female Epicauta leucocoma Champ., desig. J.D. Pinto, 1981 [1982]

Paralectotype of Epicauta leucocoma [BMNH]: Paralectotype / Syntype / Acapulco, Guerrero. Höge / Epicauta leucocoma Ch. / Godman - Salvin Coll., Biol. Centr.-Amer. / Paralectotype Epicauta leucocoma Champ., desig. J.D. Pinto, 1981 [1982]

Paralectotype of Epicauta leucocoma [BMNH]: Syntype / Tepanistlahuaca, Mexico. Salle Coll. / 2332 / Godman Salvin Coll., Biol. Centr.-Amer. / Epicauta leucocoma Ch.

Paralectotype of Epicauta leucocoma [BMNH]: Syntype / Acapulco, Guerrero. Höge / Epicauta leucocoma Ch. / Godman - Salvin Coll., Biol. Centr.-Amer.

\section{Epicauta (Epicauta) pedalis LeConte, 1866}

Non type material: México: Baja California Sur: Bahía de Las Palmas, La Paz: 29-VII-1973, 1 specimen (L. Aragonés leg.) (Epicauta pedalis LeConte, M.A. Bologna det.) [MAB] (Fig. 6b); Hotel Finisterra, Cabo San Lucas: 8/14-IX-1978, 1 
specimen (J. P. Donahue; K. E. Donahue) (Epicauta pedalis LeConte, J. D. Pinto det., 1987 [NHMLA]; Triunfo: 8-VII1919, 1 specimen (G. F. Ferris) [NHMLA].

\section{Epicauta (Epicauta) rufipennis (Chevrolat, 1834)}

Non type material: Guatemala: Baja Verapaz: Purula [Purulhá]: 2 specimens (Champion leg.) (Godman - Salvin Coll., Biol. Centr.-Amer.) (Epicauta rufipennis Chevr. female) (Epicauta rufipennis (Chev.) det. J.D. Pinto 1987) [BMNH]; Purula [Purulhá]: 3 specimens (Champion leg.) (Godman Salvin Coll., Biol. Centr.-Amer.) (Epicauta rufipennis (Chev.) det. J.D. Pinto 1987) [BMNH].

MÉXICO: 1 specimen (74-48) (Epicauta rufipennis (Chev.) det. J.D. Pinto 1987) [country record] [BMNH]; 1 specimen (luridipennis Dugès t. Haag) (F. Bates 81.19) (Epicauta rufipennis (Chev.) det. J.D. Pinto 1987) [BMNH]; 4 specimens (Truqui Mexico) (Fry Coll. 1905-100) (Cantharis (Epicauta) rufipennis Chevr. Mexico) (Epicauta rufipennis (Chev.) det. J.D. Pinto 1987) [BMNH]; 1 specimen (luridipennis Dugès t. Haag) (F. Bates 81.19) (Epicauta rufipennis (Chev.) det. J.D. Pinto 1987) [BMNH]. Chiapas: Tuxtla Gutiérrez - Rizo de Oro: 8-V-1994, 3 specimens (C.R. Beutelspacher) [CNINIBUNAM]. Distrito Federal: Ixtapalapa: 4-VII-1946, 1 specimen, Leguminose, O. Zwergakacie. [CNIN-IBUNAM]; Mexico City: 2 specimens (Höge) (Godman - Salvin Coll., Biol. Centr.-Amer.) (Epicauta rufipennis (Chev.) det. J.D. Pinto 1987) [BMNH]; Guanajuato: Guanajuato: 1 specimen (Mexico, Sallé Coll.) (Cantharis rufipennis Chevr. apud Sallé) (Godman - Salvin Coll., Biol. Centr.-Amer.) (Epicauta rufipennis (Chev.) det. J.D. Pinto 1987) [BMNH]. Guerrero: $6 \mathrm{~km}$ Chilpancingo - Omilteme: 28-V-86, 5 specimens (H. Brailovsky) [CNIN-IBUNAM] (Fig. 3a); Chilpancingo: 29-V1986, 6 specimens (E. Barrera) [CNIN-IBUNAM]; Guerrero: Chilpancingo, 4600 ft.: June, 2 specimens (H.H. Smith leg.) (Godman - Salvin Coll., Biol. Centr.-Amer.) (Epicauta rufipennis Chevr.) (Epicauta rufipennis (Chev.) det. J.D. Pinto 1987) [BMNH]; Chilpancingo, $4600 \mathrm{ft}$.: June, 1 specimen (H.H. Smith leg.) (Godman - Salvin Coll., Biol. Centr.-Amer.) [BMNH]; Mescala: (H.H. Smith leg.) (Epicauta rufipennis Chevr.) (Godman - Salvin Coll., Biol. Centr-Amer.) (Epicauta rufipennis (Chev.) det. J.D. Pinto 1987) [BMNH]; Planta Nueva, Mezcala: 1-VII-1969, 1 specimen, trampa de luz $(\mathrm{H}$. Pérez R.) [CNIN-IBUNAM]; Presa El Caracol: 19-VI-87, 1 specimen (E. Barrera) [CNIN-IBUNAM]. México: Real de Arriba; 6300 ft.: VII-1937, 1 specimen (H.E. Hinton leg.) (DF) (Hinton Coll. B.M. 1939.583) (Epicauta rufipennis (Chev.) det. J.D. Pinto 1987) [BMNH]; Temascaltepec: 1911, 4 specimens (G.B. Hinton leg.) (DF) (Hinton Coll. B.M. 1939.583) (Epicauta rufipennis (Chev.) det. J.D. Pinto 1987) [BMNH]; Temascaltepec: 1911, 3 specimens (G.B. Hinton leg.) (DF) (Hinton Coll. B.M. 1939.583) (Epicauta rufipennis (Chev.) det. R.B. Selander 1953) (Epicauta rufipennis (Chev.) det. J.D. Pinto 1987) [BMNH]; Temascaltepec: 1931, 1 specimen (G.B. Hinton) [CNIN-IBUNAM]; Valle de Bravo: 25-VI-1960, 1 specimen, trockenen Strauch (J. Hendrichs S.) [CNIN-
IBUNAM]. Michoacán: $5 \mathrm{~km}$ W Ciudad Hidalgo (Rt. 4, Km 198), 6720 ft.: 28-VI-1948, 1 specimen, scrub mesophytic (E. Werner \& W. Nutting leg.) (Epicauta rufipennis (Chevr.), J.D. Pinto det., 1987) [MAB]; $5 \mathrm{~km} \mathrm{~W}$ of Ciudad Hidalgo, $6720 \mathrm{ft}$. (Rt. 4, Km 198): 28-VI-1948, 1 specimen, scrub mesophytic (F. Werner \& W. Nutting leg.) (E. rufipennis Chev. det F. Werner) [BMNH]. Morelos: $9 \mathrm{~km}$ E of Cuernavaca, $5400 \mathrm{ft} .:$ 23-VI1948, 1 specimen, old lava flow, dry mesophytic (F. Werner \& W. Nutting leg.) (E. rufipennis Chev. det F. Werner) [BMNH]; 9 km E Cuernavaca, 5400 ft.: 23-VI-1948, 2 specimens, old lava flow dry mesophylic (W. Nutting \& F. Werner leg.) (E. rufipennis, F.G. Werner Collection) (E. rufipennis (Chevr.), F. Werner det.) [MIZA]. Nayarit: Ahuacatlán: Barranca del Oro: 31-VII-1971, 1 specimen (S. Z. C.) [CNIN-IBUNAM]. Oaxaca: Km 7 al O de Díaz Ordaz, 1701'49"N-96'28'20"O: 29-VI-1996, 2 specimens (E. Barrera, H. Brailovsky) [CNINIBUNAM]; Monte Albán: V-1982, 8 specimens (J. Hendricks S.) [CNIN-IBUNAM]; Oaxaca (Mexico Sallé Coll.) (Godman Salvin Coll., Biol. Centr.-Amer.) (Cantharis rufipennis Chevr. = luridipennis [?] = ochreipennis [?] = ochreaceipennis [?] = ochreipennis Dug.) (2307) (Epicauta rufipennis (Chev.) det. J.D. Pinto 1987) [BMNH]; Oaxaca (Mexico Sallé Coll.) (Godman - Salvin Coll., Biol. Centr.-Amer.) (Epicauta rufipennis (Chev.) Det. J.D. Pinto 1987) [BMNH]; Oajaca [sic]: 3 specimens (58-135) (Epicauta rufipennis (Chev.) det. J.D. Pinto 1987) $[\mathrm{BMNH}]$ [one without head]; Oaxaca: 1 specimen (Hoege) (Godman - Salvin Coll., Biol. Centr.-Amer.) (Epicauta rufipennis Chevr.) (Epicauta rufipennis (Chev.) det. J.D. Pinto 1987) [BMNH]; Oaxaca: 1 specimen (Hoege) (Godman Salvin Coll., Biol. Centr.-Amer.) (Epicauta rufipennis Chevr.) [BMNH]; Oazaca [sic]: 1 specimen (luridipennis Dugès t. Haag) (F. Bates 81.19) (Epicauta rufipennis (Chev.) det. J.D. Pinto 1987) [BMNH]; Oaxaca: 1 specimen (Mexico, Sallé Coll.) (Cantharis rufipennis Chevr. apud Sallé) (Godman Salvin Coll., Biol. Centr.-Amer.) (Epicauta rufipennis (Chev.) det. J.D. Pinto 1987) [BMNH]; Oaxaca: 1 specimen (Mexico, Sallé Coll.) (Cantharis rufipennis Chevr. apud Sallé) (Godman - Salvin Coll., Biol. Centr.-Amer.) [BMNH].

Epicauta (Epicauta) tenebrosa Werner, 1949

TYPE MATERIAL: Paratypes of Epicauta tenebrosa (3 specimens) [BMNH] (Fig. 6c): Tucson, Ariz. Aug. 1935 Bryant / female / grassland $6800 \mathrm{ft}$ / F. Werner leg. / Paratype Epicauta tenebrosa Werner / Paratype Epicauta tenebrosa Werner / Epicauta tenebrosa Werner; F. Werner det. / BM 1993-53

Paratype of Epicauta tenebrosa [BMNH]: Sabino Can., 714.32 E.D. Ball / Paratype Epicauta tenebrosa Werner / Paratype Epicauta tenebrosa Werner / BM 1993-53

Paratype of Epicauta tenebrosa [MIZA]: Tucson Ariz Aug. 1935 Bryant / male / Epicauta tenebrosa Werner / Paratype Epicauta tenebrosa Werner / F.H. Parker Collection / Epicauta tenebrosa Werner det. F. Werner

Paratype of Epicauta tenebrosa [MIZA]: Tucson Ariz Aug. 1935 Bryant / female / Epicauta tenebrosa Werner / Paratype Epicauta tenebrosa Werner / F.H. Parker Collection 
Appendix II.- Characters used for phylogenetic inference:

1. Cuticle of legs black (0) or primarily orange to brownish-orange (1).

2. Elytral cuticle dark, similar in color to head and pronotum (0); lighter, entirely tan, contrasting with black head and pronotum (1).

3. Elytral vestiture rather uniform in color (0); lighter on margins or suture, darker on disk (1)

4. Elytral disk not vittate (0); elytral disk with a narrow longitudinal vitta composed of cinereous setae (1)

5. Maxillary palp entirely dark (0); lighter, brownish-orange at least in part (1)

6. Head and pronotum finely, shallowly punctate (0); coarsely, deeply punctate (1)

7. Male antennae with segments III to X weakly modified (0); markedly modified, wider and compressed (1)

8. Male antennae with intermediate segments elongate, much longer than wide (0); intermediate segments widely broadened (1)

9. Male antennae with segment I weakly modified or distinctly curved anteroapically but not inflated (0); inflated (1)

10. Posterior fore tibial spur in male straight, spiniform (0); shorter, robust, tapered to apex and curved ventrally (1)

11. Outer hind tibial spur similar in shape to inner spur, not expanded at apex (0); outer spur broader than inner spur, apically truncated (1)

12. Fore tarsal segments of male relatively narrow with moderately well developed tarsal pads (0); relatively broad and thickly padded (1)

13. Middle legs tarsal segment I of male not modified (0); inflated (1)

Apéndice II.- Caracteres utilizados para la inferencia de relaciones filogenéticas.

1. Tegumento de las patas negro (0) o mayoritariamente anaranjado a castaño-anaranjado (1).

2. Tegumento elitral oscuro, de coloración similar a la cabeza y pronoto (0); más claro, enteramente castaño-bronceado, en contraste con la cabeza y pronoto negros (1).

3. Indumento elitral de color muy uniforme (0); más claro sobre los márgenes o la sutura, más oscuro en el disco (1).

4. Disco elitral sin franja longitudinal (0); con una estrecha franja longitudinal de pilosidad grisácea (1).

5. Palpos maxilares enteramente oscuros (0); más claros, castaño-anaranjados al menos en parte (1).

6. Cabeza y pronoto fina y superficialmente punteados (0); gruesa y profundamente punteados (1).

7. Antenas del macho con los segmentos III a X débilmente modificados (0); netamente modificados, ensanchados y comprimidos (1).

8. Antenas del macho con los segmentos intermedios alargados, mucho más largos que anchos (0); segmentos intermedios ampliamente ensanchados (1).

9. Antenas del macho con el segmento I débilmente modificado o distintamente curvado antero-lateralmente, pero no hinchado (0); hinchado (1).

10. Espina apical de las protibias del macho recta, espiniforme (0); más corta, robusta, acuminada hacia el extremo y curvada ventralmente (1).

11. Espina apical externa de las metatibias similar a la a la interna, no ensanchada en el ápice (0); espina externa más ancha que la interna y truncada en el ápice (1).

12. Protarsómeros del macho relativamente estrechos, con almohadillas de cerdas tarsales moderadamente desarrolladas (0); relativamente anchos, con almohadillas densamente desarrolladas (1).

13. Tarsómero I de las patas medias del macho no modificado (0); hinchado (1).

\begin{tabular}{llllllllllllll} 
& 1 & 2 & 3 & 4 & 5 & 6 & 7 & 8 & 9 & 10 & 11 & 12 & 13 \\
\hline E. crassitarsis & 1 & 0 & 1 & 1 & 1 & 0 & 0 & 0 & 0 & 1 & 1 & 0 & 1 \\
E. tenebrosa & 1 & 0 & 1 & 0 & 0 & 1 & 0 & 0 & 0 & 1 & 1 & 0 & 0 \\
E. pedalis & 1 & 0 & 1 & 0 & 0 & 1 & 1 & 0 & 0 & 1 & 1 & 0 & 0 \\
E. leucocoma & 1 & 0 & 0 & 0 & 1 & 0 & 1 & 0 & 0 & 1 & 0 & 0 & 0 \\
E. cupraeola & 1 & 0 & 1 & 1 & 1 & 0 & 1 & 0 & 0 & 1 & 0 & 0 & 0 \\
E. basimacula & 1 & 0 & 1 & 0 & 1 & 0 & 1 & 1 & 0 & 0 & 1 & 1 & 0 \\
E. diana & 1 & 1 & 0 & 0 & 0 & 0 & 1 & 1 & 0 & 0 & 0 & 1 & 0 \\
E. rufipennis & 0 & 1 & 0 & 0 & 0 & 0 & 0 & 0 & 0 & 0 & 1 & 0 & 0 \\
E. cora & 0 & 1 & 0 & 0 & 0 & 0 & 1 & 0 & 1 & 0 & 1 & 0 & 0 \\
\hline
\end{tabular}

